\title{
Notes
}

\section{Appurtenancy Reconceptualized: Managing Water in an Era of Scarcity}

\author{
Olivia S. Choe
}

\section{THE NEED TO REASSESS REGULATED RIPARIANISM}

Until recently, the eastern United States has been blessed with an abundance of water; unlike the arid West, shortages in the East have historically been "rare and short-lived." During the past few decades, however, water has increasingly become scarce, due to recurring droughts and burgeoning urban and suburban populations. ${ }^{2}$ A severe drought struck

1. Joseph W. Dellapenna, The Law of Water Allocation in the Southeastern States at the Opening of the Twenty-First Century, 25 U. ARK. LiTTLE ROCK L. REV. 9, 9 (2002) [hereinafter Dellapenna, The Law of Water Allocation]; see also George A. Gould, Water Rights Systems, in WATER RIGHTS OF THE EASTERN UNITED STATES 7, 8 (Kenneth R. Wright ed., 1998) (noting that water resources in the East were historically abundant); A. Dan Tarlock, Discovering the Virtues of Riparianism, 9 VA. ENVTL. L.J. 249, 249 (1990) (same).

"Eastern" states, for purposes of this Note, are those east of Kansas City, Missouri. Western states are governed by prior appropriation doctrine or dual riparian-appropriation regimes. See Joseph W. Dellapenna, Riparianism [hereinafter Dellapenna, Riparianism], in 1 WATERS AND WATER RIGHTS 87, 88-89 (Robert E. Beck ed., 1991).

2. See Robert H. Abrams, Water Allocation by Comprehensive Permit Systems in the East: Considering a Move Away from Orthodoxy, 9 VA. ENVTL. L.J. 255, 259 (1990); Richard C. Ausness, Water Use Permits in a Riparian State: Problems and Proposals, 66 KY. L.J. 191, 191 (1977); Lynda L. Butler, Allocating Consumptive Water Rights in a Riparian Jurisdiction: Defining the Relationship Between Public and Private Interests, 47 U. PITT. L. REV. 95, 96-97 \& n.3 (1985) (claiming that scarcity has caused growing problems for eastern states since the 1970s due to droughts, rapid population growth, extensive commercial development, and pollution of available water supplies); James N. Christman, Riparian Doctrine, in WATER RIGHTS OF THE EASTERN UNITED STATES, supra note 1, at 21, 29; Dellapenna, The Law of Water Allocation, supra note 1, at 10 . But see Tarlock, supra note 1, at 250 (arguing that, while eastern water sources are "stressed," protection of nonconsumptive instream uses, rather than consumptive uses, is the primary challenge); A. Dan Tarlock, Introduction, 24 WM. \& MARY L. REV. 535, 537-38 
the East Coast in $2002,{ }^{3}$ forcing residents in rural Maine to stop flushing toilets and washing dishes, ${ }^{4}$ significantly damaging crops in the Midwest, ${ }^{5}$ and leading New Jersey to ban lawn watering. ${ }^{6}$ But that drought was only the latest and harshest of several that have hit the region since the 1980s. Rapid population growth and commercial development in and around eastern cities have also contributed to shortages, ${ }^{8}$ in some cases leading to interstate disputes. ${ }^{9}$ Scientists predict that erratic precipitation patterns will

(1983) (suggesting that water problems in the East arise not from too much consumption, but rather from land-use problems and nonconsumptive uses).

3. See Douglas Jehl, Development and a Drought Cut Carolinas' Water Supply, N.Y. TIMES, Aug. 29, 2002, at A1 ("[A] drought... is now affecting more than a third of the United States ....").

4. See Blaine Harden, After Dry Year, Maine Is Now Soaked, N.Y. TIMES, June 25, 2002, at A14 (describing measures taken by Maine residents during "the driest year on record in this normally rainy state").

5. See Harvests Suffering Because of Drought, N.Y. TIMES, Aug. 13, 2002, at A10 ("A brutal drought across the grain belt will result in the smallest corn and soybean harvest since the mid1990 's ....").

6. See Ronald Smothers, New Jersey Bans Lawn Watering as a Lingering Drought Worsens, N.Y. TIMES, Aug. 21, 2002, at B2 (noting that " 7 of the last 12 months were the driest in the state's history and that August was shaping up as the driest August ever").

7. See Dellapenna, The Law of Water Allocation, supra note 1, at 48 (noting that southeastern states suffered "three major droughts in the 1980s"); Jehl, supra note 3 (observing that "accumulated rainfall since 1998" is "more than forty inches below normal"); Kirk Johnson, Drought Rules End, but They May Come Again Another Day, N.Y. TIMES, Oct. 31, 2002, at B1 (discussing the "drought cycle of drier than normal weather" that has hovered over the East since 1998, and the belief of some officials "that more frequent droughts were likely in coming years"); Joy Powell, Sugar-Beet Farmers To Get Disaster Aid, STAR TRIB. (Minneapolis-St. Paul), Nov. 19, 2003, at D2 (stating that drought struck Minnesota farmers in both 2001 and 2002); Three States Delay Water-Sharing Plan, N.Y. TIMES, July 16, 2002, at A11 (describing a drought in the Southeast that has "lasted four years").

8. See Butler, supra note 2, at 98 (arguing that "rapid population growth" and "extensive commercial development ... are beginning to cause water supply problems to arise even when drought conditions do not exist"); Jehl, supra note 3 (discussing weather abnormalities in the Carolinas that have been "compounded by sprawling growth" and have "sent water use spiraling ahead even of population increases and ... cut into supplies of water that would have otherwise recharged aquifers, rivers and streams"); Emily Shartin, Corporations Add Loop to Water Cycle; Recycling Efforts Earn Praise from Water Officials, BOSTON GLOBE, Feb. 5, 2004, LEXIS, Nexis Library, Boston Globe File ("In recent years, explosive residential growth has taxed local supplies, forcing many suburban communities to impose water bans and other restrictions to rein in use.").

9. One interstate dispute arose recently between Virginia and Maryland; another involved Alabama, Florida, and Georgia. See Virginia v. Maryland, 124 S. Ct. 598, 603 (2003) (describing the dispute over rights to divert water in the Potomac River that arose when Maryland officials objected to Virginia's proposal to construct a new intake facility in the river, arguing that it would encourage urban sprawl); Dustin S. Stephenson, The Tri-State Compact: Falling Waters and Fading Opportunities, 16 J. LAND USE \& ENVTL. L. 83, 84 (2000) (claiming that "sprawling development and booming industry in and around the Atlanta, Georgia, area has sparked a three state dispute between Alabama, Florida, and Georgia over water rights in the Chattahoochee River"); Three States Delay Water-Sharing Plan, supra note 7 (observing that Alabama, Florida, and Georgia have delayed for the twelfth time the implementation of their water-sharing plan, and reviewing the conflicting claims of the states on water in the Apalachicola-Chattahoochee-Flint River system). 
persist, producing recurring droughts in years to come; ${ }^{10}$ continued growth in demand will only exacerbate the consequences of weather shifts.

For policymakers, water shortages present three central challenges. First and most obviously, scarcity reminds us of the limits of our natural resources, and forces us to consider conservation measures. Second, scarcity requires that we assess the efficiency of water allocation and usage. Third-especially in the context of water, a universally necessary resource-equity demands that basic needs be met, and that one group of users not be allowed to exclude another group from an essential resource. In recent decades, water shortages have compelled eastern lawmakers to face these three issues-conservation, efficiency, and equity-directly. The result has been growing dissatisfaction with the legal regime that had historically governed the distribution of water rights in the East: common law riparianism.

Under riparianism, "an owner of land abutting a waterbody has the right to have the water continue to flow ... subject to the equal rights of each owner to make strictly limited use of the water."11 Riparian landowners, also called riparians, "share the common benefits that arise from adjacency to defined bodies of water." 12 Although riparian law had governed surface water in the East from the time of the first AngloAmerican settlers, ${ }^{13}$ it came under increasing criticism during the latter half of the twentieth century. From a conservation standpoint, riparianism failed to protect against excessive diversions by riparians, or to ensure minimum stream flows for the public. ${ }^{14}$ From an efficiency standpoint, riparian rights were inherently uncertain because they were correlatively defined, and thus could shift over time as neighboring users and uses changed; ${ }^{15}$ uncertainty, in turn, inhibited investment and prevented the development of markets in transferable water rights. ${ }^{16}$ And from an equity standpoint, riparianism was accused of favoring private agrarian interests. ${ }^{17}$ Moreover, because rights

10. Scientists studying global warming predict that droughts will recur and become more severe. Frank D. Roylance, Climate Change 'Entering the Unknown': No Doubt Human Activity Is Altering Earth's Atmosphere, Experts Say, BALT. SUN, Dec. 3, 2003, at 4A; see also Dellapenna, The Law of Water Allocation, supra note 1, at 86-87 (observing that shortfalls are expected to become more common).

11. Dellapenna, Riparianism, supra note 1, at 206.

12. Id. at 89 . law).

13. Id. at 206-12 (describing the origins of American riparianism in the English common

14. WILLIAM GOLDFARB, WATER LAW 25 ( $2 \mathrm{~d}$ ed. 1988).

15. Abrams, supra note 2, at 257-58, 262-63; Dellapenna, The Law of Water Allocation, supra note 1 , at 16.

16. Dellapenna, The Law of Water Allocation, supra note 1, at 16. Transferability of water rights was also impeded by the appurtenancy requirement, which I discuss in detail below. See infra Part II.

17. Butler, supra note 2, at 99 (noting the argument that "the common law restricts redistribution of water resources for public use"). 
were determined by ex post litigation, riparianism - like any common law regime-lacked a procedural mechanism for reallocating resources to those in need during times of scarcity. ${ }^{18}$

In the hopes of addressing these doctrinal shortcomings and better dealing with water shortages, approximately half of the eastern states formerly governed by common law riparianism established water permit systems, also known as permitting systems. ${ }^{19}$ These regulated riparian statutes-often adopted in response to scarcity concerns ${ }^{20}$-envision a rationalized, administrative approach to water rights allocation. ${ }^{21}$ In theory, regulated riparianism requires that all direct users obtain a limited-duration, renewable permit from a state administrative agency. ${ }^{22}$ This presumably allows the agency to make comprehensive ex ante decisions about preferred uses and impacts on other users, rather than resolve single disputes in ex post litigation. Agencies also have authority to reallocate water during times of shortage. ${ }^{23}$ While these regulatory schemes are usually meant to be comprehensive, certain groups of users are often exempt from the permit requirement. ${ }^{24}$ In contrast with common law riparianism, use on nonriparian land is generally allowed under permitting systems. ${ }^{25}$

What has become apparent over the last few decades, however, is that regulated riparianism suffers from its own weaknesses and, more importantly, has failed to solve many of the problems associated with traditional riparian law. Because of the exemptions accorded large groups of users, regulated riparianism appears "piecemeal," incoherent, and protective of inefficient uses. ${ }^{26}$ Even in those cases where permits are required, agencies tend to favor existing or grandfathered uses, thus preventing reallocation from lower- to higher-value uses. $^{27}$ In addition, because permits create rights that are temporary and often "use-specific,"

18. See Dellapenna, The Law of Water Allocation, supra note 1, at 16; Tarlock, supra note 1, at 249 .

19. Joseph W. Dellapenna, Issues Arising Under Riparian Rights: Replacing Common-Law Riparian Rights with Regulated Riparianism, in WATER RIGHTS OF THE EASTERN UNITED STATES, supra note 1, at 35, 37.

20. See Abrams, supra note 2, at 255; Dellapenna, The Law of Water Allocation, supra note 1 , at 10 ; Gould, supra note 1 , at 13 .

21. The systems are varied; the description here summarizes only the more common features. See Dellapenna, Riparianism, supra note 1, at 417.

22. Dellapenna, supra note 19 , at 42.

23. Dellapenna, The Law of Water Allocation, supra note 1, at 36-37; Dellapenna, Riparianism, supra note 1, at 540-46.

24. See, e.g., Dellapenna, The Law of Water Allocation, supra note 1, at 72 (describing Georgia's exemption of farm uses, which "remain far and away the largest use of water in Georgia"); see also Dellapenna, Riparianism, supra note 1, at 457-58 (describing exemptions for domestic and agricultural uses).

25. See infra note 141 and accompanying text.

26. George William Sherk, Eastern Water Law: Trends in State Legislation, 9 VA. ENVTL. L.J. 287, 290-91 (1990); Tarlock, supra note 1, at 249.

27. Dellapenna, The Law of Water Allocation, supra note 1, at 37-38 (noting that agencies seldom deny a permit, but rather tend to impose conditions on renewal). 
voluntary transfer markets have failed to develop. ${ }^{28}$ Agencies also often fail to institute conservation-oriented norms in their permitting decisions. ${ }^{29}$ Finally, agencies have yet to develop satisfactory methods for allocating rights during shortages. ${ }^{30}$ In short, permitting systems have not proved much more successful than their common law predecessor in addressing problems of conservation, efficiency, and equity.

It is thus time for eastern policymakers to reassess regulated riparianism. Indeed, some states are currently in the process of intensely reviewing their water allocation laws, while those that lack permitting schemes are likely to impose some mode of regulation in the near future. ${ }^{31}$ Most eastern water law scholars believe that the answer is more comprehensive management and greater centralization of control. ${ }^{32}$ Richard Ausness, for instance, calls for the abolition of exemptions for large-scale users, increased centralization and coordination of administration, and more detailed planning for shortages. ${ }^{33}$ Joseph Dellapenna likewise characterizes less-than-comprehensive schemes as "an unseemly hodgepodge of requirements," 34 and advocates the creation of "effective comprehensive planning mechanisms." ${ }^{35}$ But is a policy of greater centralization and

28. See Abrams, supra note 2, at 281; Richard Ausness, Water Rights Legislation in the East: A Program for Reform, 24 WM. \& MARY L. REV. 547, 547-48 (1983); Dellapenna, The Law of Water Allocation, supra note 1, at 38.

29. See, e.g., Donna Sheehan Fitzgerald, Note, Extending Public Trust Duties to Vermont's Agencies: A Logical Interpretation of the Common Law Public Trust Doctrine, 19 VT. L. REV. 509, 509-10 (1995) (arguing that recent decisions in Vermont have stripped agencies of their ability to consider the public's interests in permitting decisions, unless the legislature has expressly given them that ability); see also infra notes 190-195 and accompanying text (describing the failure of permitting agencies to protect minimum stream flows).

30. See Dellapenna, supra note 19 , at 44 (claiming that agencies "free up far less water through the renewal process" and "tend to promote lower-valued uses rather than higher-valued uses" through fee rates and exemptions); Dellapenna, The Law of Water Allocation, supra note 1, at 36 (criticizing agencies for consulting with large water users during times of scarcity, rather than relying on administrative expertise, and stating that "administering agencies prefer to use ... allocative methods least likely to provoke litigation or other difficulties for the agency").

31. Bradford Bowman, Instream Flow Regulation: Plugging the Holes in Maine's Water Law, 54 ME. L. REV. 287, 310 (2002) (suggesting that it is likely that Maine will consider minimum stream flow regulations "as the state reevaluates the need to control water consumption"); Dellapenna, The Law of Water Allocation, supra note 1, at 88 (noting that Georgia has expressly undertaken a review of its regulatory scheme).

32. An exception is Robert Abrams, who in some instances favors targeted regulatory solutions over comprehensive ones. See Abrams, supra note 2, at 275-76. Abrams's argument is that regulation may either be too specific, regulating where unnecessary, see $i d$. at 274 , or may not be specific enough, see id. at 277. As a solution, he proposes ways to improve agency performance, such as better data collection, differential management of different types of water, transferable rights, price incentives, and clearer policy guidance. See id. at 279-83. In short, Abrams's focus is on how regulatory institutions, as currently structured, might improve their performance. My emphasis is instead on how alternative institutional structures and possibilities might contribute to better water management.

33. Ausness, supra note 28 , at 589.

34. Dellapenna, Riparianism, supra note 1, at 445; see also Sherk, supra note 26 , at 290-91 (criticizing piecemeal approaches as creating greater uncertainty).

35. Dellapenna, Riparianism, supra note 1, at 448. 
increased managerial control necessarily the wisest approach? Are there alternative governance regimes that might achieve greater efficiency, higher levels of conservation, or a viable market in water rights?

Drawing on the extensive common property literature, this Note argues that such alternatives are indeed available. A wide body of scholarship in anthropology and institutional economics demonstrates that local users in a variety of contexts, from lobster fishing to irrigation, have been able to develop sustainable methods for managing scarce, common-pool resources, thereby overcoming a tragedy of the commons without the need for government regulation. This Note asserts that the organizational and institutional insights offered by common property scholarship are relevant to contemporary water management.

The Note begins by suggesting that the common property model ${ }^{36}$ may not be such a remote concept in eastern water law after all. Indeed, close consideration of traditional riparian law reveals the outlines of the common property model embedded in the doctrine itself. Specifically, Part II argues that the appurtenancy requirement within riparian law-restricting riparian rights to appurtenant owners and restricting usage to appurtenant landbears distinct similarities to key features of common property regimes. Limiting rights to those owning riparian land functioned as a proxy for creating an exclusive community ${ }^{37}$ while restricting usage to appurtenant land capped, in a rough way, total usage of the resource. ${ }^{38}$ Drawing on the appurtenancy doctrine, as well as the common property literature, I urge greater attention to certain central principles of resource conservation and management-principles that the appurtenancy doctrine, properly understood, can be seen to support.

I should be clear from the outset about the goals of such an interpretation of the appurtenancy requirement. Identifying similarities between the appurtenancy doctrine and common property regimes is meant to illuminate structural values that have proved durable in a variety of contexts. In particular, I emphasize the success of groups of users who are closest to a common-pool resource at managing against its scarcity. For critics of riparianism who may be skeptical of the wisdom of returning to

36. Various scholars have used various terms to describe common property regimes. I follow Thomas Dietz and his coauthors and use the term "common property" to denote "a kind of management arrangement created by humans rather than a characteristic iof the resource itself," and the term "common-pool" resource to denote "resources from which it is hard to exclude users." Thomas Dietz et al., The Drama of the Commons, in THE Drama OF THE COMmons 3, 17 (Elinor Ostrom et al. eds., 2002).

37. Carol M. Rose, The Several Futures of Property: Of Cyberspace and Folk Tales, Emission Trades and Ecosystems, 83 MINN. L. REV. 129, 132 (1998) (describing limited common property as "property held as a commons among the members of a group, but exclusively vis-à-vis the outside world").

38. Related doctrines, such as the watershed requirement, assisted in setting a cap on total usage. See infra notes 106-1 18 and accompanying text. 
the common law for inspiration, I would stress that it is appurtenancy's underlying principles - the principles of proximity to, and familiarity with, the resource at stake-and not merely the formal doctrinal rules that continue to bear relevance.

In fact, the rigorous requirements of the appurtenancy doctrine have been significantly modified in the last century and a half, and in many jurisdictions they no longer strictly govern. Part III examines case law reflecting this doctrinal shift and concludes that the decline of the appurtenancy requirement was the inevitable result of another key doctrine in riparian law: the reasonable use requirement, under which riparian rights are correlative and are limited only by the rights of other riparian proprietors. ${ }^{39}$ I argue that whereas the appurtenancy doctrine relied on a fundamental limiting approach to resources, the reasonable use doctrine, as interpreted and applied by the courts, relied instead on an inherently tolerant and expansionist ethic. Contrasting these two strands within riparianism serves several purposes: It provides a doctrinal explanation for the weakness of the appurtenancy requirement, it suggests a historical account of the law's failure to conserve, and it highlights a distinctionimportant for resource-management purposes-between rules that limit usage and those that balance users' interests.

Part IV returns to the context of regulated riparianism, and argues that the appurtenancy and reasonable use doctrines have important implications for ongoing management of surface water in the East. ${ }^{40} \mathrm{I}$ first note that existing regulatory schemes tend to replicate reasonable use doctrine and conclude that, in their current form, they are unlikely to effectively resolve scarcity problems. I then explore potential alternatives to comprehensive regulation that might better reflect appurtenancy's respect for those closest to a resource and their ability to conserve. While recognizing that smallscale community management may be unrealistic in the eastern water context, and a return to appurtenancy proper undesirable, I nevertheless urge consideration of institutional models combining greater local control with broader government oversight. Such "nested enterprises"41 can offer the advantages of both the commons and the state, while potentially

39. See, e.g., Tyler v. Wilkinson, 24 F. Cas. 472,474 (C.C.D.R.I. 1827) (No. 14,312) ("[N]o proprietor has a right to use the water to the prejudice of another. ... [T] he right being common to all ..., no one has a right to diminish the quantity which will, according to the natural current, flow to a proprietor below.... There may be, and there must be allowed of that, which is common to all, a reasonable use."); see also Dellapenna, Riparianism, supra note 1, at 241 .

40. Placing surface water and groundwater under separate legal regimes has been subject to widespread criticism because it ignores the hydrologic cycle. See, e.g., GEORGE A. GOULD \& DOUGLAS L. GRANT, CASES AND MATERIALS ON WATER LAW 335 (6th ed. 2000); T.E. Lauer, Reflections on Riparianism, 35 Mo. L. REV. 1, 15 (1970). Discussion of the need for joint management of surface and ground water is beyond the scope of this Note.

41. ELINOR OSTROM, GOVERNING THE COMMONS: THE EVOLUTION OF INSTITUTIONS FOR COLLECTIVE ACTION 101-02 (1990) (describing a system of "nested enterprises"). 
mitigating their respective weaknesses; by incorporating appurtenancy into the modern regulatory context, they may thus provide the best opportunity yet to improve conservation, achieve greater efficiency, and ensure equity in eastern water usage.

\section{THE APPURTENANCY REQUiREMENT AS COMMON PROPERTy REgIME}

At its core, riparian water law is about the entitlement of those bordering on a watercourse to certain use rights. ${ }^{42}$ The word "riparian" derives from the Latin ripa, which means the bank of a stream. ${ }^{43}$ Under the appurtenancy doctrine, a component of riparianism, only those who own property abutting the relevant body of water are entitled to access and use the water; ${ }^{44}$ in addition, water can only be used on adjacent parcels of land. ${ }^{45}$ This dual requirement has been subjected to substantial criticism, ${ }^{46}$ characterized as outdated and "anachronistic," 47 accused of burdening urban and industrial expansion, ${ }^{48}$ blamed for "the development of uneconomical 'bowling-alley' parcels of land," 49 and denounced for impeding the creation of marketable water rights and the increase in economic efficiency that many claim would follow. ${ }^{50}$ Indeed, overcoming the appurtenancy doctrine has been cited as "one of the princip[al] motives [behind] the enactment of

42. See supra notes 11-12 and accompanying text.

43. Dellapenna, Riparianism, supra note 1, at 87 (citing Johnson v. McCowen, 348 So. 2d 357, 360 n.3 (Fla. Dist. Ct. App. 1977)).

44. See, e.g., Tyler, 24 F. Cas. at 474 ("In virtue of [riparian land] ownership [the riparian proprietor] ... has a right to the use of the water ...."); Thompson v. Enz, 154 N.W.2d 473, 483 (Mich. 1967) ("[R]iparian rights are not alienable, severable, divisible or assignable apart from the land which includes therein or is bounded by a natural watercourse."); see also Dellapenna, Riparianism, supra note 1, at 219 (stating that "riparian rights have always depended on the ownership of land abutting a stream [or lake or sea]" and citing cases).

45. See, e.g., Gould v. Eaton, 49 P. 577, 578 (Cal. 1897) (holding that a riparian owner's right is "appurtenant to the land bordering on the stream, and does not give him the right to divert the water to lands which are not riparian to the stream"); Kennebunk, Kennebunkport \& Wells Water Dist. v. Me. Tpk. Auth., 71 A.2d 520, 530 (Me. 1950) (holding that any use of riparian water on nonriparian land is per se unreasonable unless acquired by purchase, grant, or eminent domain).

46. "Perhaps no feature of riparian law has received more adverse and critical comment than the concept that the waters are reserved for the benefit of the lands along the stream ...." GouLD \& GRANT, supra note 40 , at 237 . Commentators also widely criticize the reasonable use doctrine - the other key feature of riparianism. The primary complaint is that the reasonable use doctrine produces rights that are uncertain, likely to change over time, insecure, and therefore not conducive to investment. See, e.g., Tarlock, supra note 1, at 249-50 (describing and then questioning this critique). I take up the reasonable use doctrine as it relates to the appurtenancy doctrine in Part III.

47. GOLDFARB, supra note 14 , at 25.

48. GOULD \& GRANT, supra note 40 , at 237.

49. JESSE DUKEMINIER \& JAMES E. KRIER, PROPERTY 40 (5th ed. 2002).

50. GOLDFARB, supra note 14 , at 25 . It is worth noting, however, that criticism of the appurtenancy requirement has not been uniform. See, e.g., JOHN E. CRIBBET, ILLINOIS WATER RIGHTS LAW 28 (1958) ("[The appurtenancy doctrine] does not appear to be a major problem. Practically, water can be most efficiently used close to its source and land with riparian rights can always be purchased."). 
a regulated riparian statute." ${ }^{251}$ This Part reconsiders the appurtenancy doctrine in some detail and asserts that its underlying principles may prove more useful for resource management than its critics typically suggest.

The idea that the restrictions imposed by riparian law may have functioned as a common property regime has not gone unnoticed. Carol Rose, in arguing that common property regimes are more common than is generally recognized, briefly notes that "riparian law in the nineteenth century effectively turned river-bank landowners into participants in common property regimes... from which outsiders were excluded. Building on Rose's intuition, this Part fleshes out in more detail the various ways in which riparian law created, or at least attempted to create, a common property scheme, and compares this scheme to common property regimes in a variety of contexts. My goal here is to illuminate key principles for governing scarce resources.

\section{A. The Ownership Requirement}

\section{Access Restrictions in Common Property Regimes}

Under traditional riparian law, only those who owned property bordering a watercourse were entitled to riparian rights. ${ }^{53}$ Conceptually, this ownership restriction limited access to water to a community of easily identifiable users. It is what Henry Smith would characterize as an exclusion rule, ${ }^{54}$ and it has proved central to conservation and effective management of common-pool resources in a variety of contexts. ${ }^{55}$ Exclusivity facilitates the development of social norms that favor conservation of scarce resources. James Acheson, in his study of Maine lobstermen, describes harbor gangs as exclusive groups in which membership is usually necessary in order to gain access to the resource. ${ }^{56}$ Indeed, some gangs require land ownership in order to gain entry, thereby

51. Dellapenna, The Law of Water Allocation, supra note 1, at 35.

52. Rose, supra note 37, at 179.

53. See supra note 44.

54. See Henry E. Smith, Exclusion Versus Governance: Two Strategies for Delineating Property Rights, 31 J. LEGAL STUD. 453, 454-55 (2002) [hereinafter Smith, Exclusion Versus Governance] (characterizing exclusion rules as "gatekeeper" rules concerned with "boundaries"); Henry E. Smith, Exclusionary and Property Rules in the Law of Nuisance, 90 VA. L. REV. (forthcoming June 2004) (manuscript at 21, on file with author) [hereinafter Smith, The Law of Nuisance] (characterizing common property regimes as exclusionary).

55. See, e.g., OSTROM, supra note 41 , at 62 (highlighting the strict limitations on "[a]ccess to well-defined common property [in Törbel, Switzerland]").

56. JAMES M. ACHESON, THE LOBSTER GANGS OF MAINE 64 (1988) (claiming that new fishermen face "resistance" that "almost amounts to an initiation" upon attempting to enter a harbor gang, and that "[s]ome entrants are never accepted"). 
paralleling riparianism's appurtenancy requirement. ${ }^{57}$ Because groups are limited in size, members are more likely to form "long-term, multistrand ties with one another," 58 which in turn generate norms about "'proper' behavior." 59 In the fishing context, proper behavior means eschewing overfishing: "[T]here is a strong feeling that all members should have equal access to the resource.... Too much success, or success earned the wrong way...can generate envy, hostility, and gossip."60 Lobstering is recognized as a zero-sum game, and those who play too aggressively are disliked. ${ }^{61}$ Indeed, it is noteworthy that the most exclusive gangs, which place the greatest emphasis on longstanding kinship and community ties, ${ }^{62}$ are the ones that have "voluntarily agreed to limit the number of traps they fish." $" 63$

Studies of Japanese mountain villages, ${ }^{64}$ Spanish huerta irrigation communities, ${ }^{65}$ Cree Indian fisheries, ${ }^{66}$ and Kwakiutl Indian potlatching practices $^{67}$ likewise emphasize the relationship between exclusivity and sustainable resource usage. These communities developed detailed harvesting rules or fishing practices that prevented exhaustion of the resource at stake. As Bonnie McCay and James Acheson put it, territoriality-or "restricting access to a defined body of people who inhabit or lay claim to a particular territory"-provides "the basis for the development of more restrictive common property institutions.... If we

57. Id. at 67. Land ownership is necessary, but not always sufficient. See id. at 68 ; see also Carol M. Rose, Expanding the Choices for the Global Commons: Comparing Newfangled Tradable Allowance Schemes to Old-Fashioned Common Property Regimes, 10 DUKE ENVTL. L. \& POL'Y F. 45, 63 (1999) ("Although newcomers may sometimes enter CPRs [common property regimes], perhaps through purchase of land within the community, these would-be new entrants may well have to undergo a seasoning period before being allowed full participation.").

58. ACHESON, supra note 56, at 49; see also id. at 23-47 (detailing longstanding kinship and community ties).

59. Id. at 33 .

60. Id. at 56. Acheson characterizes a "skilled," "easygoing," "admired" fisherman as an ideal, but notes that it is rare. $I d$.

61. Id. ("Fishermen ... are convinced that a fixed number of legal-size lobsters inhabit any given area. If one man takes them, another cannot.").

62. Id. at 67 ("No newcomer can possibly enter such gangs.").

63. Id. at 154 .

64. OSTROM, supra note 41 , at 65-69 (describing the detailed harvesting rules and collective work practices that developed in closed village communities).

65. Id. at 69-82.

66. Fikret Berkes, Common-Property Resource Management and Cree Indian Fisheries in Subarctic Canada, in THE QUESTION OF THE COMMONS: THE CULTURE AND ECOLOGY OF COMMUNAL RESOURCES 66, 70, 74, 87 (Bonnie J. McCay \& James M. Acheson eds., 1987) (observing that the Cree Indians engage in "community hunting/fishing/trapping [in an] area with a reasonably well defined boundary" and hold "exclusive use-rights," and describing the enforcement of "“proper' fishing methods and practices" through social norms).

67. D. Bruce Johnsen, The Formation and Protection of Property Rights Among the Southern Kwakiutl Indians, 15 J. LEGAL STUD. 41, 47, 61 (1986) (arguing that exclusive property rights held by tribes, or numayms, allowed numaym chiefs to implement wealth-maximizing practices, such as adjustments in fishing levels to prevent overfishing). 
can keep others out, it makes sense for us to do something about our own behavior. ${ }^{, 68}$ In these communities, to which access is often strictly guarded, ${ }^{69}$ centuries-long traditions ${ }^{70}$ and "trial and error" experience breed conservationist norms. $^{72}$

Limiting group size also facilitates the monitoring and enforcement of usage rules. ${ }^{73}$ Small, enclosed communities benefit from "rich opportunities for mutual monitoring," which reduce the cost of finding violators. ${ }^{74}$ Both Acheson's lobster gangs and Spanish huerta irrigation systems display these traits. ${ }^{75}$ Moreover, because community members are repeat players, the threat of social sanctions and disrepute are often enough to produce adherence to usage rules. ${ }^{76}$ Fikret Berkes notes that among Cree Indians, "[e]ffective social mechanisms ensure adherence to rules which exist by virtue of mutual consent.... People who violate these rules suffer ... social disgrace." ${ }^{, 7}$ Similarly, social prestige drives Kwakiutl

68. Bonnie J. McCay \& James M. Acheson, Human Ecology of the Commons, in THE QUESTION OF THE COMMONS: THE CULTURE AND ECOLOGY OF COMMUNAL RESOURCES, supra note 66 , at 1,11 .

69. See, e.g., OSTROM, supra note 41 , at 68 (describing the practice of patrolling for unauthorized users in Japanese mountain villages).

70. Id. at 58 .

71. Rose, supra note 57 , at 56.

72. See, e.g., Berkes, supra note 66 , at $77-79,83$ (describing the Cree solution to the common-pool problem, which uses practices that are based on extensive knowledge of a resource developed over time).

73. See Rose, supra note 37 , at 140 ; id. at 157 ("In [common property regimes], informal norms and user-created enforcement techniques may go some distance toward self-policing and perimeter defense.").

74. Rose, supra note 57, at 64. Richard Epstein in fact attributes the appurtenancy requirement in riparian law to this desire to monitor for "overexploitation of the common pool." Richard A. Epstein, Why Restrain Alienation?, 85 COLUM. L. REV. 970, 970 (1985); id. at 981 (suggesting that the ambivalence in riparianism toward the sale of water rights arises out of a worry of introducing "a more intensive use, which [would] diminish the correlative rights of other claimants to the common pool"); id. at 982 (characterizing the disfavor toward nonriparian uses as the result of "the fear of surcharge against the common pool"); see also id. at 983 (discussing Roman usufructuary rights, which also could not be sold to third parties, and which Epstein attributes to a fear of "more intensive or destructive use[s] by the new party in possession").

75. ACHESON, supra note 56, at 74-76 (describing the "codified set of rules" that govern "boundary defense" and that are a result of the "encapsulated political system" in which the harbor gangs exist (internal quotation marks omitted)); OSTROM, supra note 41, at 73-74 (describing a traditional irrigation system in Valencia, in which users withdraw water from a ditch in a specified sequence, and thus are able to monitor the withdrawals of those users before and after them in line).

76. See ACHESON, supra note 56, at 51 (describing cooperation within cliques); ROBERT C. Ellickson, ORDER Without LAW: HOW NEIGHBORS SETTle Disputes 52-62 (1991) (explaining the long-term accounting in which ranchers engage); Rose, supra note 57, at 65 . See generally ROBERT AXELROD, THE EVOLUTION OF COOPERATION (1984) (finding that repeat play can produce cooperation even among self-interested individuals).

77. Berkes, supra note 66, at 87. 
Indians to engage in lavish potlatching practices, which D. Bruce Johnsen sees as a way to ensure territorial exclusion. ${ }^{78}$

Finally, exclusivity allows community members to maintain a sense of control and autonomy. As one commentator has pointed out, "[P]roducers [in a common property situation] seem to oppose and flagrantly to violate any outside restriction on their practices, even when they would almost certainly regulate themselves if left in control." ${ }^{, 79}$ Barton Thompson's study of water institutions in the western United States illustrates the same point. In these institutions, where outsiders are regarded somewhat suspiciously, ${ }^{80}$ local users have been able to implement customized rules to conserve scarce water supplies much more successfully than has the state. ${ }^{81}$

\section{The Ownership Restriction in the Common Law}

Common property regimes thus succeed in conserving resources in part by excluding others. Exclusivity maintains user control, provides opportunities for extensive monitoring, and facilitates the development of restrictive use norms by those closest to the resource. As Anthony Scott and Georgina Coustalin have noted, restrictions on transferability of riparian water rights likewise seek to protect "the exclusivity of the right in the stream-wide group of users." 82 I therefore turn to cases from the nineteenth and early twentieth centuries, which-while perhaps not always strictly adhering to the appurtenancy requirement-demonstrate its inherently exclusionary tendencies.

For instance, in cases dealing with grants of water rights to nonriparians, early courts held that such grantees were not entitled to full riparian rights. In Gould v. Eaton, for example, the defendants, who were nonriparians, had contracted for the right to place a tunnel on the grantor's

78. Johnsen, supra note 67, at 61-65. Although Johnsen refers to the property rights as "exclusive," id. at 41 , they were rights exclusive to a tribe, or numaym, $i d$. at 61 , and were thus common within the tribe.

79. E.N. Anderson, Jr., A Malaysian Tragedy of the Commons, in THE QUESTION OF THE COMMONS: The CULTURE AND ECOLOGY OF COMMUNAL RESOURCES, supra note 66, at 327 , 341.

80. See Barton H. Thompson, Jr., Institutional Perspectives on Water Policy and Markets, 81 CAL. L. REV. 671, 700, 724-39 (1993) (describing users' unresponsiveness to outside interests and unwillingness to trade water with external users).

81. See id. at 698 (detailing a number of arrangements, including pro rata sharing, limits on groundwater pumping, well-spacing rules, hydrologic barriers, taxes, and tiered pricing structures, that users have developed for conservation purposes and that initially appear to have improved efficiency). The importance of local control has elicited comment in other contexts. See OSTROM, supra note 41, at 64 (noting that an important feature of communal-property management in Törbel, Switzerland, is that appropriators themselves make decisions).

82. Anthony Scott \& Georgina Coustalin, The Evolution of Water Rights, 35 NAT. RESOURCES J. 821, 831 (1995). Riparian law's failure to achieve this objective is taken up in the next Part. 
riparian land in order to divert water. ${ }^{83}$ The California Supreme Court affirmed an injunction prohibiting the diversion and explained the extent of the defendants' entitlement under such a grant: "[It] gave [defendants] no right in the land which is adjacent to the stream, and they took by the contract no riparian rights in the waters of the stream ...."84 While the defendants might have had a contractual right that was good as against the grantor, they had no rights as against other riparian proprietors. They were, in effect, excluded from the riparian community. Other courts have come to the same conclusion. ${ }^{85}$

In one such case, Roberts $v$. Martin, the plaintiff was a gristmill operator, and the defendants owned nonriparian land near the plaintiff's parcel. ${ }^{86}$ In addition, the defendants purchased from an upstream riparian owner the rights to one of the springs on his land. The court held that their diversion of water violated the plaintiff's riparian rights. ${ }^{87}$ The court noted that the doctrine of reasonable use as between riparian proprietors did not include "the case of an interference by a stranger, who, by any means, or for any cause, diminishes the flow of the water; for this also is wholly wrongful, and no question of the reasonableness of his action in causing the diminution can possibly arise." "\$8 The court in essence announced a per se rule against water use by nonriparians, or "strangers," under which no such use could ever be found reasonable.

Perhaps more ambiguously, in Williams $v$. Wadsworth the Connecticut Supreme Court recognized the rights of a nonriparian owner based on his longstanding usage and acceptance within the riparian community. ${ }^{89}$ The plaintiff, a nonriparian, had purchased in 1851 from a riparian landowner "the right to build and maintain upon the land a dam," from which he diverted water via a pipe to his house. ${ }^{90} \mathrm{He}$ used the water for domestic purposes, and also sold some of it to other town residents. ${ }^{91}$ The defendant, who owned a one-acre upstream parcel, began in 1881-thirty years after

83. 49 P. 577, 577-78 (Cal. 1897).

84. Id. at 578 .

85. See, e.g., Duckworth v. Watsonville Water \& Light Co., 110 P. 927, 932 (Cal. 1910) (Shaw, J., concurring) ("The water cannot be severed from the land and transferred to a third person so as to give him the title and right to remove it, as against other riparian owners. The grantor alone will be estopped by such a conveyance."); Hendrix v. Roberts Marble Co., 165 S.E. 223 (Ga. 1932); Stratton v. Mt. Hermon Boys' Sch., 103 N.E. 87, 89 (Mass. 1913); see also Scott \& Coustalin, supra note 82 , at 883-84 (concluding that while nonriparians were allowed by some courts to contract for use rights, they could only sue their grantor, because courts would not recognize nonriparian claims against other riparians).

86. 77 S.E. 535 (W. Va. 1913).

87. Id. at 536 .

88. Id. at 537 (quoting Dumont v. Kellogg, 29 Mich. 420, 422 (1874)) (emphasis added).

89. 51 Conn. 277 (1883).

90. Id. at 277.

91. Id. The sale of water to town residents may also have suggested to the court that the plaintiff was somewhat akin to a municipal water company, an entity usually excepted from the appurtenant ownership requirement. See infra note 138. 
plaintiff had begun his usage-to divert water via "an acqueduct of his own ... to his residence and premises," no part of which was riparian. ${ }^{92}$ The plaintiff's brief noted that after considerable expense, the defendant succeeded in supplying himself with water, which he used

for domestic and culinary purposes, for watering his horses and cattle, for supplying a fountain or fountains, and for sprinkling his lawn and the street in front of his dwelling-house. A considerable quantity of the water thus diverted has run to waste, and none of it has been restored to the stream. ${ }^{93}$

The court upheld the claim of the nonriparian plaintiff as against the riparian defendant, finding that he had acquired a prescriptive right through adverse use for the required statutory period. ${ }^{94}$ Given the uncertainties that often surround prescriptive rights in riparian law and the narrow scope courts generally give to such rights, ${ }^{95}$ it seems likely that the court considered other factors in finding the right. Indeed, the court took special notice of the fact that the plaintiff had secured from "all lower proprietors" a release by deed from any claims for his diversion..$^{96}$ Moreover, at the time that the dispute arose, the plaintiff had been using the water for approximately thirty years, while the defendant had been diverting for less than three years. The court thus seemed to find that the nonriparian plaintiff's usage- because longstanding and because explicitly accepted by the other riparian proprietors-was riparian, while the riparian defendant's diversion was not. Although the case might be read as an equitable exception to the ownership requirement, it can also be interpreted as confirming the community principle behind the appurtenancy requirement. The release from liability that the plaintiff had sought and received from the other riparian proprietors, and his long-accepted diversion of the water, demonstrated that his usage had survived the community's scrutiny. In other words, his nonriparian status was outweighed by his proven entry into the web of interrelationships and monitoring that characterizes a common property regime.

Finally, in a number of cases, courts granted plaintiffs injunctions against nonriparian diversions in part out of a concern that such nonriparian usage might ripen into a prescriptive right. The Roberts court, for example,

92. Williams, 51 Conn. at 282 .

93. Id. at 285 .

94. Id. at 306.

95. See Dellapenna, Riparianism, supra note 1, at 308 (describing the "uncertainties in the reasonable use theory of prescriptive rights," the difficulty with determining when the prescriptive period begins, and the tendency of courts to limit title acquired by prescription to "the least adverse use actually made by the claimant").

96. Williams, 51 Conn. at 301-02. 
noted that "[t]he unlawful act of defendants will, in time, ripen into an adverse right if permitted to continue. Equity affords complete and speedy redress in the premises." 97 Such cases may have reflected the fear that a nonriparian user might forcibly gain access to the resource without properly entering the riparian community, again confirming the exclusivity principle behind appurtenancy.

The ownership component of the appurtenancy doctrine thus arguably gestures toward a key feature of common property management-limiting access to a group of users defined by their proximity to the resource at stake. A wide range of scholarship illuminates the ways in which such a restriction can assist in the conservation of a common-pool resource, ${ }^{98}$ and early case law reveals such dynamics guiding courts in their decisions. While exclusivity in itself is not necessarily admirable, other ideas central to appurtenancy-the ability of those close to the resource to develop sustainable practices and to monitor each other's usage, and the importance of user control over resource management-deserve attention in the establishment of any regime governing a scarce resource.

\section{B. The Use Restriction}

The other component of the appurtenancy doctrine is its use restriction, under which water may only be used upon riparian land. ${ }^{99}$ In this Section, I argue that appurtenancy and its sister doctrines operated more or less as a

97. Roberts v. Martin, 77 S.E. 535, 538 (W. Va. 1913); see also Webb v. Portland Mfg. Co., 29 F. Cas. 506, 509 (C.C.D. Me. 1838) (No. 17,322) ("If, then, the diversion of water complained of in the present case is a violation of the right of the plaintiffs, and may permanently injure that right, and become, by lapse of time, the foundation of an adverse right in the defendant, I know of no more fit case for the interposition of a court of equity, by way of injunction, to restrain the defendants from such an injurious act."); Anaheim Union Water Co. v. Fuller, 88 P. 978, 981 (Cal. 1907) ("Nor is the [riparian] owner ... required to show in order to procure an injunction, any actual present damage. The diversion, by lapse of time, may grow into a right. To prevent such result, an injunction will be awarded." (quoting Stanford v. Felt, 16 P. 900, 900-01 (Cal. 1886) (citations omitted))); Gould v. Eaton, 49 P. 577, 578 (Cal. 1897) ("[T]he claim of the defendants that they have a right to divert ... authorizes [plaintiff] to invoke the aid of equity in order that this claim may not ripen into a right."); Clinton v. Myers, 46 N.Y. 511, 520-21 (1871) (enforcing the riparian defendant's right to the natural flow of water, even if it was asserted through a "bad motive," because the plaintiff, whose business would be destroyed were the defendant allowed to assert his rights, had acquired no prescriptive right in the water).

98. A recent scholar reviewing and synthesizing scholarship on common-pool resources confirms that small group size, shared norms, and interdependence among group members, supplemented by cheap exclusion technologies, are increasingly recognized as key facilitating conditions for common property regimes. See Arun Agrawal, Common Resources and Institutional Sustainability, in THE DRAMA OF THE COMMONS, supra note 36, at 41, 62-63.

99. See supra note 45 and accompanying text. 
cap on total usage. I examine a number of cases demonstrating courts' sense that riparian land within the same watershed served as a rough proxy for the amount that could safely be withdrawn from the stream. I then consider usage restrictions in a range of common property settings to emphasize the importance of setting limits on withdrawal, as well as the competence of those most familiar with a resource in determining the appropriate level of withdrawal.

\section{The Use Restriction in the Common Law}

The case of Williams $v$. Wadsworth illustrates the limitation principle at work. ${ }^{100}$ As described above, the plaintiff in Williams, though a nonriparian, had been diverting water, with the permission of all lower riparians, for approximately thirty years. ${ }^{101}$ When the defendant, a riparian, began diverting water to a nonriparian parcel, the plaintiff sued and was granted an injunction. The court's discussion of the extent of the defendant's riparian rights is telling:

Being a riparian owner the defendant has the right to consume water upon riparian premises ... . But this use is to be confined to riparian land. This limitation.... stands upon the necessity for a restraining rule in order to secure something for all, and upon the presumption that the brook will supply the absolute needs of as large an area as is usually held in riparian ownership. ${ }^{102}$

The court then warned that "[i]f land not riparian may draw to itself, equally with land riparian ... then land not riparian may take precedence of land riparian and deprive it of water for either man or beast." 103 In short, the court's decision seems to rely on a rough estimate that the amount of water needed to supply riparian parcels generally approximates the amount of water that may safely be withdrawn without depleting the stream. ${ }^{104}$

Some readers will likely question how effective the appurtenancy requirement could be at confining total usage, given that a riparian landowner could in theory purchase larger and larger parcels of land and,

100. 51 Conn. 277.

101. See supra notes 89-96 and accompanying text.

102. Williams, 51 Conn. at 304 (emphasis added).

103. Id.

104. See also Butler, supra note 2 , at 108 (describing physical constraints on water use as aimed at providing "reasonabl[e] assur[ance] that sufficient water would exist in the future"); Lauer, supra note 40 , at $5 \& \mathrm{n} .13$ (describing the appurtenancy requirement as arising out of "a fear that riparian owners would suffer a shortage of water if nonriparians were admitted to its use"). 
under the unity-of-title rule that applies in most riparian states, ${ }^{105}$ could thereby exercise her riparian rights on an increasing area of land. In response, I would emphasize that the court's opinion in Williams is offered not to prove the conceptual limits of the use restriction, but rather to illustrate the underlying principles at work in the case law-conserving against scarcity and relying on the judgment of user-owners as to parcel size. In addition, and perhaps more importantly, the appurtenancy doctrine did not function alone, but rather operated in conjunction with other limitations on the total area of land that could benefit from riparian water rights.

First, many courts applied a "watershed limitation" in addition to the appurtenancy requirement; the conjunction of the two rules reflects a desire to limit withdrawal from the stream. ${ }^{106}$ In Anaheim Union Water Co. v. Fuller, the court held that "[l]and which is not within the watershed of the river is not riparian thereto, and is not entitled ... to the use or benefit of the water from the river, although it may be part of an entire tract which does extend to the river." ${ }^{107}$ Although a parcel might be contiguous to a river, only that portion of the parcel within the river's watershed was considered riparian. The court went on to explain the logic behind this doctrine:

The principal reasons for the rule... are that, where the water is used on such land, it will ... return to the stream, so far as it is not consumed, and that, as the rainfall on such land feeds the stream, the land is . . entitled, so to speak, to the use of its waters. ${ }^{108}$

Or as Richard Ausness explains, "The watershed limitation is based on the assumption that land beyond the watershed is outside the boundaries

105. This rule, in contrast to the source-of-title rule, see infra note 106 , "treats all lands in a contiguous tract under a single ownership ... as riparian so long as any part of the tract touches the waterbody-regardless of the history of prior ownership," Dellapenna, Riparianism, supra note 1, at 223. For a definition of the source-of-title and unity-of-title rules, see Donald R. Levi \& Kenneth C. Schneeberger, The Chain and Unity of Title Theories for Delineating Riparian Land: Economic Analysis as an Alternative to Case Precedent, 21 BUFF. L. REV. 439, 440 (1972). For evidence that the unity-of-title rule results in forty percent more riparian land than the source-oftitle rule, see Dellapenna, Riparianism, supra note 1, at 223 n.104.

106. See Dellapenna, Riparianism, supra note 1, at 226-27. Another restriction that has been applied to riparian rights in some states is the source-of-title, or chain-of-title, rule. Under that test, only land that has been riparian at all times retains the riparian rights; thus, when a riparian tract is subdivided, those parcels no longer contiguous to the watercourse lose their riparian status, "even if [later] reunited with riparian land under a single ownership." Id. at 223. Under the sourceof-title rule, riparian land can only diminish. The rule has mainly been applied in western states. See Levi \& Schneeberger, supra note 105 , at 440 (noting that the source-of-title rule applies only in certain western states, and thus questioning whether it "will be a part of the riparian doctrine of any eastern state").

107. 88 P. 978,980 (Cal. 1907).

108. Id. 
established by nature for riparian ownership ...."109 In other words, the watershed requirement aimed to preserve the body of water in the stream by allowing it to be used only upon land that naturally returned such water to the stream. ${ }^{110}$ In this way, the appurtenancy and watershed rules worked together to reduce the effects of withdrawals.

Some courts imposed even further limitations. For instance, the court in Town of Gordonsville $v$. Zinn limited riparian usage not only to land within the same watershed but also to land acquired in a single transaction. ${ }^{111}$ The plaintiff town owned a reservoir that supplied its residents with water. The defendant owned a very small parcel of riparian land-a twenty-five-foot strip-upstream from the reservoir, as well as a parcel downstream, upon which her house was located. Although the downstream parcel was also riparian, it had been acquired separately from the upstream parcel. ${ }^{112}$ The town sued the defendant when she began diverting water from her upstream strip to her downstream parcel, since water thus diverted bypassed the reservoir altogether. ${ }^{113}$ The court ultimately held for the plaintiff, enjoining the defendant from further diversion. ${ }^{114}$

Putting aside for the moment the plaintiff's distribution of the water to nonriparian town residents, ${ }^{115}$ the court's opinion reveals a sense, similar to that displayed in the Williams opinion, that the size of riparian parcels will generally protect against depletion of the water source. Although the holding ultimately relied on the fact that the downstream receiving parcel was in a separate watershed from the upstream diverting parcel, and thus was nonriparian with respect to that diversion, ${ }^{116}$ the court nevertheless made sure to expound upon the single-ownership rule. Quoting from Farnham's treatise on water rights, the court took note of

"the rule that all land must be regarded as riparian which is within the natural watershed of the stream, the title to which is in one owner and the boundaries of which have been established in accordance with the requirements of the conditions which will best

109. Ausness, supra note 2, at 203-04; see also Butler, supra note 2, at 111-12 (highlighting that the watershed rule "appears to take into account the hydrologic cycle" and conforms to the scientific view of the watershed as an ecosystem).

110. Dan Tarlock has called for greater attention to watersheds in the definition of property rights from an ecological, hydrologic perspective. See A. Dan Tarlock, Reconnecting Property Rights to Watersheds, 25 WM. \& MARY ENVTL. L. \& POL'Y REV. 69, 81 (2000) (characterizing the use restriction as "reinforc[ing] watershed protection"). Interestingly, Tarlock sees reasonable use doctrine as part of the watershed protection element inherent in common law riparianism. Id. This account conflicts with my own. See infra Part III.

111. 106 S.E. 508 (Va. 1921).

112. Id. at 511 .

113. Id. at 513.

114. Id. at 516.

115. Supplying town residents with water from the reservoir was, of course, technically a nonriparian use. But see infra note 138 and accompanying text.

116. Zinn, 106 S.E. at 513. 
serve the interests of individual landowners.... The watershed should certainly form a limit beyond which the riparian rights cannot be claimed; but there is a question whether or not that limit is not too wide. .. . Under this rule the boundary of riparian land is restricted to land ... acquired by one transaction."

Guarding against the possibility that land within a watershed, or separate riparian parcels held by a single owner, might "recognize such a vast extent of territory as riparian land [so as to be] destructive,",118 the court thus seemed to rely on the judgment of individual purchasers by using parcel size as a rough proxy for the area that could profitably be supplied by the stream in question.

\section{Capping Mechanisms in Common Property Regimes}

Taken together, these cases suggest that the appurtenancy requirement and related doctrines functioned as a rough cap on withdrawal, by relying both on naturally arising drainage patterns and the judgment of riparian owners. The appurtenancy and single-transaction requirements in particular exhibited the law's faith that riparian proprietors would purchase parcels of sustainable size. I conclude this Section by examining a number of analogous property regimes in which usage rules function as capping mechanisms, restricting the amount that may be withdrawn from a common-pool resource. This comparison places appurtenancy's reliance on riparian owners within the context of a range of mechanisms adopted by appropriators to voluntarily restrict their own resource usage.

Multiple scholars have identified voluntary limits on total usage as a key factor in the sustainability of common property regimes. In describing the common grazing areas under the English open field system, for example, Smith notes that not only was access to common grazing areas restricted "to a small closed class of appropriators," but further restrictions on usage also applied. ${ }^{119}$ In particular, "stints," or limits on the number of animals that could graze on the commons, essentially functioned as a capping mechanism, since "one sheep cannot eat much more even if it is allowed to graze longer." 2 Stints, like the appurtenancy requirement and its sister doctrines, served as "proxies for harmful activities"; 121 the eating capacity of sheep, like the size of riparian parcels, inherently limited total usage. The success of the open field system, both in increasing productivity

117. Id. at 512 (quoting 2 Henry PhILIP Farnham, THE LAW OF WATERS AND WATER RIGHTS § 463a, at 1571-72 (1904)).

118. Id. (quoting 2 FARNHAM, supra note $117, \S 463 \mathrm{a}$, at 1571 ).

119. Smith, Exclusion Versus Governance, supra note 54, at 460.

120. Id. at 471 .

121. Id. 
and in overcoming the potential tragedy of the commons posed by communal grazing areas, has been well-documented. ${ }^{122}$ Stints, which proved extremely "effective and widespread"123 in preventing overuse, were a central component of this success.

Other examples of voluntary restrictions on usage abound. Acheson credits lobster gangs' self-imposed reductions in fishing efforts-in particular, voluntary limits on the number of traps, which necessarily limited total catch $^{124}$-for "both economic and biological benefits," including greater lobster density and higher lobstermen profits. ${ }^{125}$ Swiss villages have sustained a communal alpine economy since the thirteenth century by requiring that officials first "mark[] the trees ready to be harvested," which allows for "a careful assessment of the condition of the forest." 126 In the extensive common lands regulated by Japanese villages for centuries, "detailed authority rules specif[ied] in various ways how much of each valued product a household could harvest from the commons and under what conditions." 127 And, perhaps most pertinent to the appurtenancy context, more than one huerta irrigation system has limited water rights to certain areas of land; designations of some parcels as irrigated and some as dry have lasted for centuries. ${ }^{128}$

Examining the use restriction of appurtenancy doctrine in light of the practices of common property regimes allows us to make two observations. First, from a resource standpoint, the restriction, while no doubt often inefficient and inequitable in confining water usage to adjacent land, ${ }^{129}$ may nevertheless have stemmed from a quite rational desire to limit withdrawal by users of a scarce resource. Appurtenancy and its sister doctrines may have tried to cap usage by drawing on the proxies of adjacency, watershed boundaries, and parcel size, just as medieval peasants relied on sheeps' digestive systems, and Maine lobstermen relied on the size of standard fishing traps. Second, as a structural matter, both appurtenancy and successful common property regimes seem to have relied on the intimate knowledge of proximate user-owners in determining the appropriate level

122. See Henry E. Smith, Semicommon Property Rights and Scattering in the Open Fields, 29 J. LEGAL STUD. 131, 131 (2000); id. at 134-36 (collecting sources).

123. Smith, Exclusion Versus Governance, supra note 54, at 471.

124. Traps, like sheeps' stomachs, are finite in capacity.

125. ACHESON, supra note 56 , at $154-56$.

126. OSTROM, supra note 41 , at 65 .

127. Id. at 67.

128. Id. at 71 (highlighting such a practice in Valencia and observing that "the right to water inheres in the land itself'); id. at 76 (discussing the same for Murcia and Orihuela).

129. See supra notes $46-51$ and accompanying text. 
of withdrawal. ${ }^{130}$ For common-pool resource management, both insightsabout the need to cap withdrawal and the expertise of those closest to (and thus most familiar with) a resource in setting such caps-are essential.

\section{REASONABLE USE AND THE DECLINE OF THE APPURTENANCY REQUIREMENT}

This Note began with the premise that, in light of continuing water shortages, eastern states need to reassess current water regulation and develop more sustainable resource-management practices. Resisting the preference exhibited by most commentators for comprehensive and centralized regulation, I instead turned to an unlikely place-the appurtenancy doctrine-and suggested that appurtenancy contained certain structural features that have proved successful in governing and conserving scarce resources in a variety of common property contexts. A complete account, however, must recognize that the success of riparianism in restricting access and usage has been, at best, quite limited.

Though modern treatises still define riparian rights as those "concerning the relation of the owner of the bank of a stream to various features of the stream," 131 most commentators recognize that the appurtenancy doctrine-the feature that gives riparianism its very name $^{132}$-is today subject to numerous exceptions. "[E]very state," notes James Christman, "allows some means of transferring riparian rights apart from the land." 133 Granted, the law regarding these transfers varies from jurisdiction to jurisdiction and remains far from clear: ${ }^{134}$ Some states recognize conveyances, though whether such conveyances are valid only against the grantor, or against all other riparians, is a matter of some dispute; ${ }^{135}$ a number of states recognize the right to lease riparian water rights; ${ }^{136}$ and a fraction of all states recognize prescriptive nonriparian

130. The Swiss villagers discussed above, for example, assessed forest conditions and then determined harvest levels. See supra text accompanying note 126. Fikret Berkes similarly notes that the sustainability of Cree fishing practices in part arose from their dependence upon fish: "[A] subsistence fishery has a built-in self-limiting principle." Berkes, supra note 66, at 85; see also Agrawal, supra note 98, at 62-63 (identifying as key conditions of successful common property regimes that (1) group members are highly dependent on the common-pool resource and (2) restrictions on harvest correspond to the rate of regeneration of the resource). In this respect, the idea that reliance on a resource produces an awareness of the need to limit withdrawal is not unrelated to my claim that familiarity with a resource allows users to more accurately set sustainable withdrawal levels.

131. Dellapenna, Riparianism, supra note 1, at 87.

132. See supra note 43 and accompanying text.

133. Christman, supra note 2, at 28.

134. Dellapenna, supra note 19 , at 39.

135. Dellapenna, Riparianism, supra note 1, at 291-92.

136. See, e.g., Smith v. Stanolind Oil \& Gas Co., 172 P.2d 1002 (Okla. 1946). 
rights. ${ }^{137}$ Nevertheless, the general trend has been away from appurtenancy and toward increasing nonriparian use. ${ }^{138}$ Recent reformulations of the law likewise recognize the need for nonriparian rights. The Restatement (Second) of Torts does not consider "classification of [a use of water] as riparian or nonriparian" to be controlling, ${ }^{139}$ and the influence of this view is seen in court decisions-most notably Pyle v. Gilbert ${ }^{140}$ - that recognize nonriparian rights. And finally, the permitting systems and regulated riparian regimes that increasingly govern surface water in eastern states also recognize nonriparian rights as permissible. ${ }^{141}$

Why did the appurtenancy doctrine never really take hold, and what relevance does this have for modern resource management? In this Part, I offer two accounts. In Section A, I examine cases in which courts made exceptions to the appurtenancy requirement; this doctrinal analysis leads me to conclude that the reasonable use doctrine that increasingly governed riparian water law during the nineteenth century inherently allowed for expansion of the riparian community and the acceptable set of riparian uses. Section B offers some broader historical reasons for the failure of the appurtenancy doctrine, emphasizing the cavalier approach to natural resources that characterized the United States during the era of industrialization. In the next Part, I draw on these conclusions and suggest that the tolerance for increased usage inherent in the reasonable use doctrine continues to have significance today.

\section{A. Reasonable Use as Doctrine}

Under the reasonable use doctrine, "each owner of riparian land is permitted to use the water in a waterbody, regardless of the effect the use has on the natural flow, so long as each user does not transgress the equal

137. See Dellapenna, Riparianism, supra note 1, at 304-12 (discussing prescriptive rights and citing cases)

138. All states, even those that deny that water can be conveyed for use on nonriparian land, recognize the right of municipal water suppliers to condemn water for public water supply purposes. Id. at 299-304 (discussing condemnation of riparian rights and citing cases); see also Christman, supra note 2, at 25-26, 28. I consider condemnation of riparian rights for municipal water supply to be substantially different in character from conveyances of, or prescriptive claims to, riparian rights by private parties. My discussion here is thus not meant to apply to such exercises of eminent domain.

139. RESTATEMENT (SECOND) OF TORTS $\S 855$ (1979); see also id. $\S 855 \mathrm{cmt}$. b (suggesting that it "may be reasonable" to allow riparians to use water on nonriparian land, and finding a per se rule against nonriparian uses to be "unreasonable").

140. 265 S.E.2d 584, 589 (Ga. 1980).

141. See Patricia K. Flood \& Kenneth R. Wright, Summary of Water Rights Law in the 31 Eastern States, in WATER RIGHTS OF THE EASTERN UNITED STATES, supra note 1, at 105 (listing numerous states in which nonriparian use is allowed by permit); see also Dellapenna, supra note 19 , at 42 (claiming that "often one of the princip[al] motives of the enactment of a regulated riparian statute was to authorize the use of water on nonriparian land"). 
right of other riparians to use the water."142 The rise of reasonable use doctrine during the nineteenth century, replacing the more stringent natural flow theory of riparian rights, ${ }^{143}$ has been the subject of considerable scrutiny. ${ }^{144}$ The argument here is that reasonable use, at least as framed by nineteenth-century courts, was a doctrine inherently tolerant of expanding uses of water; as such, it operated in tension with the appurtenancy doctrine, which I have characterized as inherently restrictive.

The classic statement of riparianism in American law is Justice Story's opinion on circuit in Tyler $v$. Wilkinson. ${ }^{145}$ In that case, the lower riparian plaintiffs claimed that upstream proprietors were entitled only to water that the plaintiffs did not need. The court, however, rejected this suggestion, holding that "[t]here may be, and there must be allowed of that, which is common to all, a reasonable use." 146 While the opinion seemed to hold fast to natural flow theory in some respects, ${ }^{147}$ it also acknowledged what Morton Horwitz has called "the utilitarian criterion of valuable use [as] the ultimate source of legal rules." 148 Specifically, Story rejected the idea that riparianism would allow for "no diminution whatsoever ... for that would be to deny any valuable use."149 The Tyler case, while still nominally adhering to natural flow doctrine, thus opened the door to a balancing approach to riparian rights that would take into account "valuable use."

Further elaboration of the reasonable use doctrine has only added to its malleability. In the 1883 case of Red River Roller Mills v. Wright, for example, the Minnesota Supreme Court offered this definition of the factors to be taken into consideration in a reasonable use analysis:

In determining what is a reasonable use, regard must be had to the subject-matter of the use; the occasion and manner of its application; the object, extent, necessity, and duration of the use; the nature and size of the stream; the kind of business to which it is subservient; the importance and necessity of the use claimed by one party, and the extent of the injury to the other party; the state of

142. Dellapenna, Riparianism, supra note 1 , at 241 .

143. Under natural flow theory, also known as the English Rule, each riparian is entitled to water flow in its "natural condition, without alteration by others of the rate of flow or the quantity or quality of water." Id. at 233.

144. See, e.g., Morton J. Horwitz, The Transformation of AmERICAN Law, 17801860: THE CRISIS OF LEGAL ORTHODOXY 31-47 (1977); CAROL M. ROSE, Energy and Efficiency in the Realignment of Common Law Water Rights, in PROPERTY AND PERSUASION: ESSAYS ON THE HISTORY, THEORY, AND RHETORIC OF OWNERSHIP 163 (1994) (reprinting Carol M. Rose, Energy and Efficiency in the Realignment of Common Law Water Rights, 19 J. LEGAL STUD. 261 (1990)).

145. 24 F. Cas. 472 (C.C.D.R.I. 1827) (No. 14,312) (Story, Circuit Justice).

146. Id. at 474 .

147. See id. ("[Riparian proprietors have] a right to the use of the water flowing ... in its natural current, without diminution or obstruction.").

148. HORWITZ, supra note 144 , at 39.

149. Tyler, $24 \mathrm{~F}$. Cas. at 474. 
improvement of the country in regard to mills and machinery, and the use of water as a propelling power; the general and established usages of the country in similar cases; and all the other and evervarying circumstances of each particular case bearing upon the question of the fitness and propriety of the use of the water under consideration. ${ }^{150}$

The reasonable use analysis thus became open-ended and case-specific. Such a utilitarian approach, concerned as it is with comparing social costs and benefits, is inherently open to expansion; it allows-indeed, it encourages-courts to take into account the economic value of the infringing user's activity. As Smith notes, such tort-based rules do not protect rights, but rather focus on "the efficient use of resources. Scarcity over resources is reduced to bilateral conflicts over use." ${ }^{\prime 51}$ The key considerations are "maximiz[ing] value" and "optimal resource allocation," rather than protection against global scarcity. ${ }^{152}$ A reasonable use regime is governed by considerations of "social values and needs"153 and "general rules of permissible and impermissible human conduct"; ; ${ }^{154}$ as such, it is inherently "fluid and socially responsive." 155

Finally, consider the focus on actual injury in the reasonable use inquiry. As Justice Story put it in Tyler, "The true test of the principle and extent of the use is, whether it is to the injury of the other proprietors or not." 156 Courts often cite the doctrines of de minimis non curat lex and damnum absque injuria in rejecting plaintiffs' claims, finding damage nonexistent, or simply too small to justify a remedy. ${ }^{157}$ This rule, too, fits with an expansionist interpretation of reasonable use: Defendants will not be enjoined, even if their activities violate established rules of riparian use, unless plaintiffs can actually show injury.

Reasonable use's tolerance for expanded usage is perhaps most apparent in those cases allowing exceptions to the appurtenancy requirement. In these decisions, reasonable use essentially swallows up the

150. 15 N.W. 167, 169 (Minn. 1883). For a similarly open-ended list of factors for determining reasonable use, see RESTATEMENT (SECOND) OF TORTS, supra note 139, § 850A.

151. Smith, The Law of Nuisance, supra note 54 (manuscript at 11).

152. Id. (manuscript at 3); see also Dellapenna, The Law of Water Allocation, supra note 1, at 13-14 (characterizing the reasonable use test as "a relational test, a weighing of the social value of the two uses against each other to determine which use is more valuable to society").

153. Eric T. Freyfogle, Water Justice, 1986 U. ILL. L. REV. 481, 502 (characterizing the transition to reasonable use as a move from property-based water rights to tort-based water wrongs).

154. Id. at 503.

155. Id. at 502; see also id. at 500-01.

156. Tyler v. Wilkinson, 24 F. Cas. 472, 474 (C.C.D.R.I. 1827) (No. 14,312) (Story, Circuit Justice).

157. See GOULD \& GRANT, supra note 40, at 251 (discussing Gehlen v. Knorr, 70 N.W. 757 (Iowa 1897), in which the plaintiffs' mill was not materially affected and their claim was therefore rejected). 
appurtenancy doctrine. In Elliot v. Fitchburg Railroad, for instance, the defendants purchased a riparian parcel upstream from the plaintiff's land and diverted water to their depot to furnish locomotive engines. ${ }^{158}$ Although the diversion violated the appurtenancy rule, the court held the defendants "not liable" because the plaintiff had not "suffered actual perceptible damage." 159 Reasonableness, it held, was "a question of degree," not the absolute rule appurtenancy would impose. ${ }^{160}$

Similarly, in Jones $v$. Conn the court allowed the defendant to irrigate nonriparian land and power a gristmill over the complaint of the plaintiffs, who used the water to irrigate riparian parcels. ${ }^{161}$ In opposition to the theory of appurtenancy described above, the court noted that "whether a proposed use is... reasonable, does not depend so much upon the area of the land ... or the place of use, as upon the effect it has upon ... the other proprietors." 162 Here, the "amount of water taken ... was not sufficient to materially injure the plaintiffs," so the defendant could not be deemed a "wrongdoer." 163

Even more extreme is the Oklahoma Supreme Court's statement in Smith v. Stanolind Oil \& Gas Co. ${ }^{164}$ The plaintiffs sought to enjoin Stanolind from obstructing water flow and taking the water for nonriparian purposes. The court emphasized that nonriparian use "standing alone, [is] no criterion of the reasonableness of the use. .. [A] riparian owner has the right to make any use of water... possible, so long as he does not inflict substantial or material injury [on other riparians]." 165

Doctrinally, one can therefore link the decline of the appurtenancy doctrine-or perhaps more accurately, the refusal of courts to insist upon its strict application - to the rise of reasonable use. The appurtenancy doctrine, which we might characterize as a resource-focused limiting rule, conflicted with the user-focused balancing rule of reasonable use. This account is thus somewhat in tension with Rose's description of the reasonable use doctrine:

$[R] i p a r i a n$ law in the nineteenth century effectively turned riverbank landowners into participants in common property regimes for particular rivers, from which outsiders were excluded (no interbasin water transfers) and insiders were expected to use the common

158. 64 Mass. (10 Cush.) 191, 192 (1852).

159. Id.

160. Id. at 194.

161. 64 P. 855 (Or. 1901).

162. Id. at 860 (emphasis added).

163. Id.

164. 172 P.2d 1002 (Okla. 1946).

165. Id. at 1005 . 
resource "reasonably"-in effect, in a way that was compatible with equal correlative use by all the other riparian owners. ${ }^{166}$

In other words, Rose suggests that both place-of-use restrictions and the reasonable use doctrine were a part of the common property regime. The view offered here, however, is that reasonable use actually worked in opposition to and defeated the restrictive common property elements of appurtenancy. While reasonable use initially may have governed a community of insiders, the doctrine's tendencies to treat uses and users "reasonably," to consider the social value of activities, and to decide in favor of efficiency and productivity, would inevitably lead to expansions of the community as well as the range of accepted uses. While the Tyler test of injury initially looked only to the impact on, and competing claims of, other riparian proprietors, ${ }^{167}$ its principle of balancing and value maximization would eventually require consideration of the interests of outsiders. In short, reasonable use sooner or later tended to undermine appurtenancy.

This account of reasonable use versus appurtenancy allows us to draw a conceptual distinction among different types of what Smith calls governance rules-a distinction not fully apparent from Smith's analysis, but important for resource-management purposes. Under Smith's taxonomy, governance rules involve the "specification of proper activities" for which a resource may be used. ${ }^{168}$ Given this broad definition, both appurtenancy's use restriction and the reasonable use doctrine would qualify as governance rules, since both speak to appropriate usage: Appurtenancy specifies the parcels of land on which water may be used, while reasonable use (at least in theory) specifies the purposes for which it may be used. Smith's focus is on the relative information costs of different rules, and he thus differentiates between governance rules of greater and lesser specification. ${ }^{169} \mathrm{He}$ does not, however, distinguish between rules that limit total usage and those that merely aim to balance conflicting users' interests. He sees governance, like exclusion, ${ }^{170}$ as an "alternative method[] of preventing dissipation," 171 without recognizing that certain governance rules, such as the reasonable use doctrine, may actually facilitate increased usage of a resource. Smith notes that common property regimes often involve both exclusion rules and "rules of proper use among [group members]," which may "promote conservation and sustainability of

166. Rose, supra note 37 , at 179.

167. See supra text accompanying note 156.

168. Smith, Exclusion Versus Governance, supra note 54, at 455

169. See id. at 468 (describing different levels of detail and cost associated with different rules for a grazing commons).

170. Exclusion rules delegate decisionmaking about resource usage to the owner, by restricting access to the resource.

171. Smith, Exclusion Versus Governance, supra note 54, at 474. 
common-pool resources." 172 But he does not acknowledge that some "proper use" rules emphasize limitation, while others may focus on value maximization-a distinction that is at the heart of riparian law's shift from appurtenancy to reasonable use. Smith does briefly address the transition from natural flow theory to the reasonable use doctrine, but asserts only that "exclusion tends to give way to governance as pressure on the resource has increased," "173 without analyzing the implications of reasonable use for a resource under pressure. His analysis thus misses the key difference among governance rules that this Note has emphasized in the two riparian regimes.

Examining the limited success of the appurtenancy doctrine in relation to the reasonable use doctrine, and analyzing the cases in which courts allowed the former to give way to the latter, one can see an important conceptual distinction-limiting versus balancing-among various regimes aiming to conserve scarce resources.

\section{B. Reasonable Use as Historical Development}

The rise of reasonable use, however, is not an entirely satisfactory explanation of why appurtenancy failed to take hold. Indeed, doctrinal analysis simply begs the question: It explains what judges did, but not why they did it. In this Section, I briefly offer some suggestions as to why judges turned away from appurtenancy and constructed an ever-broadening notion of reasonable use.

Morton Horwitz's legal realist account holds that the rise of reasonable use and fall of natural flow was part of what he calls "the transformation in the conception of property" that occurred during the nineteenth century. ${ }^{174}$ The reasonable use standard was "an open-ended formula through which common law judges could implement their own conceptions of desirable social policy." 175 What I described above, somewhat agnostically, as the value-maximizing tendency of reasonable use is viewed by Horwitz in more political terms, as "central . . to the needs of industrial development ... in the nineteenth century" and "essential to economic improvement." "176 Rose summarizes Horwitz's explanation succinctly: "[L]egal developments [in water law] gave a kind of common law subsidy to capitalist developers, allowing them to inflict some injury upon weaker and less enterprising folk without having to pay for the consequences." ${ }^{177}$ Theodore Steinberg, an environmental historian, agrees: "The drive to promote industrial growth

172. Smith, The Law of Nuisance, supra note 54 (manuscript at 21-22).

173. Id. (manuscript at $50 \mathrm{n} .148$ ).

174. HoRWITZ, supra note 144 , at 31.

175. Id. at 39.

176. Id. at 40 .

177. RosE, supra note 144, at 165. 
had, in the process, reduced water to an instrument in the service of economic change. Water by the early years of the nineteenth century was well on its way to becoming a simple utility, an abstraction employed to suit economic ambitions. ... a commodity."

Other, less political explanations are available, and they complement Horwitz's account. As riparianism moved beyond New England, into southern and western parts of the country, it encountered regions where water was used less for power-an instream use that would not have found the appurtenancy doctrine unduly restrictive ${ }^{179}$-and more for consumptive uses. such as irrigation and farming. ${ }^{180}$ In these areas, a more tolerant attitude toward withdrawals by nonriparian owners for use on nonriparian land undoubtedly seemed more attractive. Moreover, once steam became a major source of energy, ${ }^{181}$ and the mill economy of the Northeast declined, "courts began to appreciate the fact that it would be efficient to increase the consumption of many streams and they began to develop a law of consumption through the reasonable use theory." 182 In short, both economic and geographic expansion of the nation likely gave impetus to doctrinal change.

Finally, the need to expand the acceptable uses of water went unchecked by any sense of scarcity. Quite simply, the humid eastern states did not face the same shortages as western states. ${ }^{183}$ Courts lacked a pressing reason to adhere to the logic of conservation and restriction embedded within the appurtenancy doctrine. With water plentiful and the economy expanding, the dominant ethic of industrialization demanded the

178. THEODORE STEINBERG, NATURE INCORPORATED: INDUSTRIALIZATION AND THE WATERS OF NEW ENGLAND 49 (1991); see also id. at $21-49$ (describing the rise of the New England mill economy); id. at 88 (noting that "water [was defined] principally in terms of its value for exchange and production"); id. at 147 (characterizing reasonable use doctrine as "flexible" and framed in terms of the "best interests of "communities," favoring "those who demonstrated that their use of the water benefited everyone, whether it actually did or not").

179. ROSE, supra note 144, at 186 ("Eastern riparian rights grew up around the use of water for power - that is, instream power ....").

180. Id. at 188 (noting that riparian owners in locations like Florida and Iowa tend to engage in more "zero-sum" uses of water, such as irrigation, than riparian owners in New England); see also Robert E. Beck, Waters, Water Rights, and This Treatise, in 1 WATERS AND WATER RIGHTS, supra note 1, at 1, 30 (documenting the greater livestock and irrigation water use in southern and midwestern regions of the country than in New England). Flatter terrain in the Midwest was more conducive to farming than the hillier land in the East, and thus a more attractive candidate for irrigation. I thank Carol Rose for highlighting this point.

181. See STEINBERG, supra note 178, at $244-45$ (describing the decline of the hydraulic mill system and the rise of steam-powered textile factories in the Merrimack Valley over the course of the nineteenth century).

182. Tarlock, supra note 1 , at 251.

183. See Gould, supra note 1, at 8-9 (comparing water resources in the East and West, and emphasizing that, "[i]n the East, water resources are relatively abundant [since the] climate is humid, irrigation is not necessary for successful farming, and demand for water has historically been low," whereas in the West, "water resources are scarce and highly variable"); David Haber, Introductory Essay, in THE LAW OF WATER ALLOCATION IN THE EASTERN UNITED STATES, at xxv, xxv (David Haber \& Stephen W. Bergen eds., 1958). 
fullest use of natural resources. ${ }^{184}$ In such a climate, courts found little need to insist on ownership or use restrictions, and plenty of reasons to tolerate expanded access and withdrawal.

This Part has offered two explanations for the weakness of the appurtenancy requirement in riparian law. As a doctrinal matter, appurtenancy and its restrictive attitude conflicted with, and succumbed to, the more tolerant balancing approach of reasonable use. As a historical matter, appurtenancy's values of limitation and conservation did not fare well under the pro-development, efficiency-maximizing policies of the nineteenth and early twentieth centuries, nor did they seem necessary in light of the seeming abundance of water. This comparison of the reasonable use and appurtenancy doctrines proves helpful as we return, in the next Part, to regulated riparianism.

\section{THE CONTINUING RELEVANCE OF APPURTENANCY'S PRINCIPLES}

Having considered in some depth the two basic doctrines of riparianism-appurtenancy and reasonable use-as well as the features of common property regimes that have enabled users to sustain and conserve scarce resources, we are now able to draw several conclusions to aid us in our evaluation of regulated riparianism: First, restricting access to a resource to its closest users can facilitate the development and enforcement of conservation norms. Second, because users are generally resistant to external oversight, placing management authority in their hands will often increase the likelihood that they will adopt effective resource usage practices. Third, because users will generally have greater familiarity with the resource and its changing dynamics than government actors, they are often better able to determine appropriate levels of usage and to limit their withdrawals accordingly. Finally, regimes that rely on a value-maximizing, balancing approach are less likely to protect scarce resources against growing demand than regimes that take a more restrictive, limiting approach. With these observations in mind, I offer a critique of current water law regimes in Section A. While a full-scale policy proposal is beyond the scope of this Note, I do suggest, in Section B, a number of ways in which the lessons of appurtenancy and common property management may be applied to water law today. 


\section{A. Reasonable Use Redux?}

I begin by drawing attention to the survival of the reasonable use doctrine under current regulatory schemes. Most statutes list a set of factors for agencies to use in deciding whether or not to grant a permit; such lists closely resemble the open-ended inquiries conducted under the reasonable use doctrine in cases such as Red River Roller Mills. ${ }^{185}$ The Regulated Riparian Model Water Code, for example, provides a list of nine factors to be taken into account by the permitting agency, including "the economic and social importance of the proposed water use and other existing or planned water uses sharing the water source."186 Such lists "can only reinforce the sense that the substantive basis for decision remains much the same as in traditional common-law litigation under the reasonable use theory of riparian rights." 187 While advocates of riparian statutes stress that such decisions are made ex ante, rather than ex post, ${ }^{188}$ I would question the extent to which moving the reasonableness inquiry from an ex post judicial decision to an ex ante administrative determination can counteract the tendency of such balancing tests to permit increased usage, instead of protecting scarce resources. As one scholar comments, "[I]n permit-based jurisdictions, allocative standards make little effort to distance themselves from their riparian ancestors." 189

Supporters of regulated riparianism may note that every permitting statute requires the administering agency to develop long-term plans to protect the source for future needs, ${ }^{190}$ and that almost all permitting statutes also "require the agency to define or protect minimum flows." ${ }^{191}$ But the existence of such statutory mandates does not ensure protection of water resources. Long-term plans, for instance, are often developed according to a list that, again, echoes the reasonable use inquiry; ${ }^{192}$ they are thus unlikely to result in greater conservation. Furthermore, statutory mandates to protect minimum flows have proved, in practice, difficult to administer, given "traditional water management" values and the "considerable discretion"

185. See supra note 150 and accompanying text.

186. THE Regulated RIPARIAN MODEL WATER CODE $\S 6 \mathrm{R}-3-02$ (Am. Soc'y of Civil Eng'rs 1997). For a summary of factors considered in other statutes, see Dellapenna, Riparianism, supra note 1 , at $495-96$.

187. Dellapenna, Riparianism, supra note 1 , at 497.

188. Dellapenna, The Law of Water Allocation, supra note 1, at 34 ("The most important difference [from the common law] is that an administering agency decides before a use begins whether it is reasonable ...." (emphasis added)); Dellapenna, Riparianism, supra note 1, at 448 (calling the permit requirement "the most significant innovation under regulated riparianism").

189. Abrams, supra note 2, at 270.

190. Dellapenna, Riparianism, supra note 1, at 522-23.

191. Id. at 529; see also Sherk, supra note 26, at 311-14 (describing minimum-flow protections).

192. Dellapenna, Riparianism, supra note 1, at 524. 
granted administering agencies. ${ }^{193}$ In Arkansas, for example, where a regulated riparian statute provides for the protection of minimum stream flows, "[t]he process of setting minimum flows has proven highly political, [resulting in] considerable modification (and reduction) of the proposed original levels of protection."194 A series of recent agency and court decisions in Vermont has severely limited the ability of the state's permitting agencies to use the public trust doctrine to protect minimum stream flows. ${ }^{195}$ Lack of strong enforcement of minimum-flow protections, combined with the persistence of reasonable use inquiries in permitting decisions and long-term planning, may thus indicate that regulated riparianism will fare no better at conserving water supply than its common law predecessor.

\section{B. Local-Global Possibilities}

Rather than press for greater centralization and control while adhering to reasonable use inquiries and multifactor tests, regulators should take a step back and consider potential alternatives to the comprehensive management model. Indeed, common property scholars have extensively documented the disastrous consequences-in both ecological and human terms - that can result from wrongheaded state intervention. ${ }^{196}$ In light of the analysis offered in this Note, I would urge serious consideration of regulatory responses that attend to scarcity in a way that incorporates the core principles of appurtenancy. In other words, while regulated riparianism

193. Id. at 533-35.

194. Dellapenna, The Law of Water Allocation, supra note 1, at 55-56.

195. In re Okemo Mountain, Inc., No. 2S0351-12A-EB (Vt. Environmental Board Sept. 18, 1990) (concluding that agencies do not have common law public trust duties, unless they are expressly delegated by statute); see also In re Okemo Mountain, Inc., No. 2S0351-12A-EB (Vt. Environmental Board Mar. 27, 1992) (allowing Okemo ski resort to increase its withdrawal of water from the Black River-though not to the extent requested by Okemo-over the objections of environmentalists, for the purpose of snowmaking); Fitzgerald, supra note 29 (describing this litigation).

Use of the public trust doctrine as a means of protecting environmental values has attracted much scholarly attention. See, e.g., Michael C. Blumm, Public Property and the Democratization of Western Water Law: A Modern View of the Public Trust Doctrine, 19 ENVTL. L. 573 (1989); James L. Huffman, A Fish Out of Water: The Public Trust Doctrine in a Constitutional Democracy, 19 ENVTL. L. 527 (1989); Joseph L. Sax, The Public Trust Doctrine in Natural Resource Law: Effective Judicial Intervention, $68 \mathrm{MICH}$. L. REV. 471 (1970). It is, however, beyond the scope of this Note.

196. See, e.g., OSTROM, supra note 41 , at 143-81 (describing a series of centralized efforts to reform resource management that have "destroy[ed] . . . effective [common property] institutions without necessarily developing effective alternatives"); Evelyn Pinkerton, Intercepting the State: Dramatic Processes in the Assertion of Local Comanagement Rights, in THE QUESTION OF THE COMMONS: THE CULTURE AND ECOLOGY OF COMMUNAL RESOURCES, supra note 66, at 344,344 ("Actions of the Canadian state, especially through [the Canadian Department of Fisheries and Oceans], have played a key role in the decline of the salmon fishery ... by both inciting and exacerbating problems that... are attributed solely to the common-property nature of the resource."). 
has until now included primarily the reasonable use strand from common law riparianism, I would instead emphasize the appurtenancy strand.

Some readers will no doubt question the feasibility of returning to the strictures of the appurtenancy doctrine. Indeed, confining water usage to adjacent bodies of land, for the benefit of the owners of those parcels, seems neither a realistic nor a desirable goal for contemporary water management. I would suggest, however, that appurtenancy need not be conceived of solely as a physical restriction. Instead, I propose here an understanding of appurtenancy as a structural, organizational concept for resource management. It is this reconceptualized notion of appurtenancy that may prove valuable for policymakers today.

\section{Reconceptualizing Appurtenancy}

The traditional understanding of appurtenancy focused on physical proximity: Only owners whose property abutted the water had rights to it, and only their adjacent land could benefit. But as the cases reveal, and as comparisons to common property scholarship highlight, the doctrine was not solely about physical proximity, but also contained certain structural principles of resource management. Limiting riparian rights to adjacent owners excluded "strangers" and thus defined a group of users who could enforce conservationist norms of behavior. Restricting usage to appurtenant parcels demonstrated a reliance on those most familiar with the resource to determine appropriate levels of usage. In other words, appurtenancy doctrine expressed a commitment to vesting resource management in those closest to, and sharing an interest in, the waterbody. In the eighteenth and nineteenth centuries, this structural commitment coincided with physical proximity; adjacency functioned as a proxy for defining the most knowledgeable community of users. But in a twenty-first-century world in which water consumption needs are vastly different, we should perhaps de-emphasize the physical requirements associated with appurtenancy and focus instead on its delegation of governance rights to those most intimate with the resource, whether physically proximate or not.

Under this definition, appurtenant users would no longer necessarily be those with property bordering a given resource, but would rather be defined as those within a given region using a resource in a similar way. Membership in a community of users would be conceived of not in terms of adjacent land ownership, but rather in terms of the particular use-whether irrigation, recreation, or municipal water supply. Appurtenancy, on this understanding, would vest management authority not in those physically 
proximate, but in those functionally proximate-both to the resource and to a like group of users. ${ }^{197}$

Putting appurtenancy to work in a contemporary water regime would thus mean recognizing the competence of communities of users in effectively governing scarce resources. At first glance, the workability of such a governance scheme in the eastern water context might seem dubious. After all, the examples of community management discussed above generally involve close-knit groups that are able to exclude outsiders because of their small size, and whose ability to conserve resources depend largely on longstanding social ties. ${ }^{198}$ While such community-based regimes might work in the context of small streams or rivers, they seem implausible when it comes to larger watercourses that may span not only great distances, but also multiple jurisdictions. ${ }^{199}$ Moreover, unlike the irrigators in huerta communities or the farmers in medieval England, the heterogeneity of water users in eastern states makes traditional collective action seem unlikely to succeed. ${ }^{200}$ And while common property management has proved successful at addressing conservation concerns, its exclusionary nature and resistance to outside interests might not sit well with those worried about efficiency and equity.

In response to such concerns, I would first suggest that appurtenant groups need not be limited to homogeneous communities of individual users; users drawing on the same body of water for similar purposes could be considered appurtenant, even if they were institutional entities. Second, I would emphasize that small-scale community-based management and

197. Physical proximity will likely continue to be common among appurtenant users; those most familiar with a resource are still often necessarily those located nearby, though perhaps not owning directly adjacent land. The point is that physical adjacency need not be the defining characteristic of appurtenancy.

198. Members of Maine's lobster gangs, for example, have "long-term, multistrand ties with one another." ACHESON, supra note 56, at 49. The Cree Indian fisheries studied by Berkes likewise relied on "social mechanisms" to enforce conservation norms. Berkes, supra note 66, at 87.

199. See supra note 9 and accompanying text.

200. Diverse interests are often involved in eastern water disputes, in both the North and the South. See, e.g., Bowman, supra note 31, at 290-91 (describing the conflicting interests of farmers, berry growers, ski area operators, salmon fishers, and environmental organizations in Maine's water resources). Similarly, the fight among Alabama, Florida, and Georgia over the Chattahoochee River arises from the competing claims of various groups of users. In Alabama, water is needed for drinking, industry, agriculture, and recreation; in Florida, for seafood cultivation and wetlands salinity preservation; and in Georgia, for pulpwood forest irrigation, farm irrigation, and a growing population. See Stephenson, supra note 9, at 85-86.

Some evidence suggests that heterogeneity among users impedes cooperation. See Pranab Bardhan \& Jeff Dayton-Johnson, Unequal Irrigators: Heterogeneity and Commons Management in Large-Scale Multivariate Research, in THE DRAMA OF THE COMMONS, supra note 36 , at 87,102 (concluding that "heterogeneity, however it might be measured, has a negative impact on cooperation" in the irrigation cases studied, because it weakens the effectiveness of social norms and sanctions). Bardhan and Dayton-Johnson do express some cautious optimism about the effects of heterogeneity under certain conditions-for example, global-scale commons, see id. at 106 - but evidence of such positive effects is preliminary and tentative. 
comprehensive government regulation are not the only options. We may do better if we avoid "the familiar trichotomy of private, communal, and state ownership," 201 and instead pay more attention to the possibilities of localstate co-management. ${ }^{202}$ As Oran Young suggests, rather than "focus[ing] exclusively on finding the right level or scale at which to address specific problems .... the key to success [may instead lie] in allocating specific tasks to the appropriate level of social organization and then taking steps to ensure that cross-scale interactions produce complementary rather than conflicting actions."203 Indeed, much recent work in common property scholarship and institutional economics more broadly has been directed toward the possibilities of local-state co-management. Thus, just as the Note drew on the first wave of common property scholarship to illuminate our understanding of the appurtenancy requirement, I now turn to more recent work in the area to inform our regulatory policies going forward. Specifically, I consider what Elinor Ostrom has called "nested enterprises," in which "[a]ppropriation, provision, monitoring, enforcement, conflict resolution, and governance activities are organized in multiple layers."204 Under such a model, respect for appurtenant communities could be embedded within a larger-scale government system.

While nested enterprises may sound intriguing in theory, readers may wonder whether such efforts work in practice, and how they would work in the context of eastern water law. In the remainder of this Note, I thererefore describe successful examples of cross-scale management. I also suggest reasons to believe that such regimes may provide the advantages of both the commons and the state, while mitigating, rather than exacerbating, their respective weaknesses. I conclude by arguing that multilevel governance may be particularly well-suited to the dilemmas facing eastern water regulators. In particular, nested regimes that embed appurtenant groups within an administrative scheme may more effectively address the three major concerns-conservation, efficiency, and equity-that surround allocation of our water supply. ${ }^{205}$

201. Agrawal, supra note 98 , at 44 .

202. Id. at 58 (arguing that "the nature of local-state relations requires more careful exploration").

203. Oran R. Young, Institutional Interplay: The Environmental Consequences of CrossScale Interactions, in THE DRAMA OF THE COMMONS, supra note 36 , at 263, 266; see also Carol M. Rose, Common Property, Regulatory Property, and Environmental Protection: Comparing Community-Based Management to Tradable Environmental Allowances, in THE DRAMA OF THE COMMONS, supra note 36 , at 233,239 (recognizing the possibility of "larger governmental institutions ... interven[ing] to organize 'nested' [common property regimes]").

204. OSTROM, supra note 41 , at 101.

205. Pollution has been and remains a major problem for eastern waters. See, e.g., STEINBERG, supra note 178, at 191 (stating that industrial waste was a significant source of pollution in the Merrimack River by the 1860s); id. at 205-06 (describing the rapid decline of New England's water quality over the nineteenth century); Tarlock, supra note 1, at 250 (arguing that protection of instream uses, rather than protection against scarcity, is the major concern for 


\section{Nested Enterprises: Some Models}

Numerous instances of successful nested enterprises exist. This Subsection explores four models and considers in each instance how norms of usage and conservation developed by appurtenant groups can be effectuated within a larger government system. These examples highlight the ways in which nested enterprises may yield the advantages of both the commons and the state, while mitigating the weaknesses of each.

One nested enterprise model, which we might call the reverse command-and-control model, utilizes state authority, expertise, and administrative resources to enforce usage rules developed by appurtenant groups to protect against scarcity. For example, the Maine lobster gangs have, in recent years, formed links with state government, which in turn aids them in the enforcement of their voluntary restrictions on fishing. Acheson notes that the inhabitants of Monhegan Island have "persuaded the legislature to pass a law forbidding fishing in Monhegan waters from June 25 to January 1," thereby making official a customary closed season that the islanders have observed since the early $1900 \mathrm{~s} .{ }^{206}$ Fishers from Swan Island likewise convinced Maine's commissioner of marine resources to enforce a self-imposed limit on the number of traps surrounding the island. ${ }^{207} \mathrm{~A}$ similar example comes from the Aleut community in Alaska, where the community controls access to the territories, and thus can control the level of fishing, but has also "made the state limit fishing effort in adjacent territories where the local stocks might be intercepted by outsiders."208

Yet another example can be found overseas, in the state of Kumaon in India, where centralized rules create "a framework for the management of forests rather than a defining straitjacket," and at the same time establish "a domain of relatively autonomous action and rule making in which local residents and their representatives can operate."209 Specifically, local authorities "make rules and enforce them," "facilitate some kinds of actions ... and restrict others," meet frequently to modify rules, and "create monitoring and sanctioning mechanisms." 210 The state government supplements these efforts by supervising recordkeeping, coordinating harvesting, providing technical assistance, and aiding in rule

eastern water). While the nested governance model could certainly prove applicable to pollution problems, the focus here is on extractive uses. A complete analysis of state and federal pollution regulation of surface water in the East is beyond the scope of this Note.

206. ACHESON, supra note 56, at 158.

207. Id. at 159.

208. Pinkerton, supra note 196, at $345,368$.

209. Arun Agrawal \& Jesse Ribot, Accountability in Decentralization: A Framework with South Asian and West African Cases, 33 J. DEVELOPING AREAS 473, 482 (1999).

210. Id. 
enforcement. $^{211}$ As these examples demonstrate, reverse command and control takes advantage of the greater skill of local users in developing rules of conservation, and places those rules under the enforcement authority of government. $^{212}$

Another nested governance model that has gained attention recently combines market-based tradable allowances with community management. Under tradable allowance schemes,

governmental regulators in effect place an upper limit or cap on the total quantity of a given resource that is to be available for use. . . . The regulators then divide the capped total into individual allowances. Henceforth they require all resource users to purchase or trade for whatever allowances they use. ${ }^{213}$

In a nested enterprise model, quotas are allocated to appurtenant communities, rather than individuals or individual entities. In Alaska, for example, some of the walleye pollock quota was allocated to native communities; similarly, New Zealand transferred forty percent of its fishery quota to the Maori. ${ }^{214}$ Such schemes incorporate groups of usersproximate both to each other and to the resource-into a larger regulatory market, thereby protecting community interests ${ }^{215}$ while maintaining the advantages of a centralized decisionmaker for setting and managing overall goals. ${ }^{216}$

In these regimes, as compared to the reverse command-and-control model discussed above, the state does not undertake enforcement of specific usage restrictions developed by the user community. Instead, it grants an appurtenant group of users a block of rights that is presumably large enough to allow the group to maintain a sustainable level of withdrawal, leaving the group to implement and enforce its own conservation norms. At the same time, the tradable allowance scheme permits user groups to operate within a broader market of uses and users. The existence of a wider market in standardized rights can facilitate transfers from lower- to higher-value uses, thereby increasing the efficiency

211. Id.

212. Indeed, we might be more comfortable with placing enforcement authority with the state, as some of the enforcement techniques employed by Maine fishermen involved misogyny and violence. See Rose, supra note 203, at 252; Rose, supra note 57, at 66-67 (stating that the traditional enforcement mechanism of common property regimes is self-help).

213. Rose, supra note 203 , at 235 . Market solutions to regulatory problems are still controversial. See infra note 254 . The point here is that they provide a model combining broader governmental oversight and appurtenant user management.

214. Tom Tietenberg, The Tradable Permits Approach to Protecting the Commons: What Have We Learned?, in THE DRAMA OF THE COMMONS, supra note 36, at 197, 210.

215. Id.

216. Id. at 222. Tietenberg does note that some co-management tradable permit systems give more control to users, and some less. Id. 
of resource usage. ${ }^{217}$ The creation of standardized rights can also facilitate coordination across different appurtenant groups-functioning as a kind of common language and in some instances leading to larger-scale conservation efforts. ${ }^{218}$

A third model-what we might call the horizontal governance modelcomes from voluntary associations of groundwater users in Southern California. These nested enterprises should be particularly persuasive not only because they involve water as opposed to fisheries or forest management, but also because they demonstrate the viability of such a model among institutional, as opposed to individual, users. The parties involved here are not members of an Indian village, or an Aleut fishing community, but include municipalities, utility companies, and private mutual corporations.

Elinor Ostrom documents the rise of "a set of institutions [established by water producers] to manage a series of groundwater basins located beneath the Los Angeles metropolitan area." ${ }^{219}$ Faced with the prospect of saltwater incursions, dropping aquifers, and uncertain rights, appropriators began to engage in a "pumping race," a classic example of a tragedy of the commons. $^{220}$ During the $1940 \mathrm{~s}$ and $1950 \mathrm{~s}$, many believed that the race would result in the destruction of the basins, with dire consequences for the water supply in southern California. ${ }^{221}$ But instead of succumbing to the tragedy, water producers entered into a series of negotiations, through which they were able to form institutional structures that combined public and private governance, ${ }^{222}$ to set restrictions on withdrawals, and to institute conservation measures. Nested within the public arena, private actors were able "to impose constraints on themselves." 223

A few features of these settlements are particularly noteworthy. First, the disputes arose among functionally appurtenant users-claimants with shared interests in the same body of water. Second, in coming up with a

217. See Rose, supra note 57 , at 59 .

218. See id. at 70-71 (noting that individual rights-holders of fishing quota systems have essentially formed new common property regimes, and that communities that have been given a stake in wildlife preservation have developed new norms of conservation "among themselves and among other communities").

219. OSTROM, supra note 41 , at 104.

220. Id. at 109.

221. Id. at 110 .

222. Ostrom discusses a few different institutional arrangements that developed. The Raymond Groundwater Basin negotiations led to an out-of-court settlement enforced in part by the state. Id. at 113-14. The Central and West Basin Water Replenishment District, an entity with public powers to tax, sue, and provide public goods, $i d$. at 133 , was created by water producers after a private association - intended to provide a forum for water producers and agencies, $i d$. at 115-failed to garner complete cooperation, id. at 128 . Importantly, private water associations, which we might term appurtenant groups, continue to actively participate in the district's decisionmaking, as do a number of public agencies, thus allowing Ostrom to characterize the entity's structure as "polycentric." Id. at 113.

223. Id. at 110 . 
solution, it was important to the users that they maintain some measure of management authority; they did not want to turn decisions over to largescale agencies, "for fear that they would lose control of the decisions being made and might end up worse off." 224 In short, they exhibited the same desire for autonomy and self-governance as members of the common property regimes discussed above. ${ }^{225}$ Third, while users maintained decisionmaking control, they did so within a larger governmental regime; the institutional solution was neither deregulation nor centralization, but rather "polycentric" systems ${ }^{226}$ of shared private-public governance. While the first two models of nested governance are largely vertical and thus somewhat hierarchical, with the state at the top and user groups at the bottom, this model vests management authority in a more horizontal, or multipronged, manner. Fourth, the costs of monitoring and enforcement were shared by the users (two-thirds) and the state (one-third). ${ }^{227}$ And finally, the negotiations among parties led to a better clarification of rights, which in turn allowed a market to develop, leading to a transfer of rights to those using them at "a higher value."228

The Ostrom study allows us to draw two important conclusions. First, appurtenant groups can be defined to include institutional users-here, the appurtenant groups were voluntary associations made up of both individual and institutional user-appropriators - who may prove just as capable of developing and enforcing conservation norms as individuals within a small community. Specifically, institutional appropriators restricted their water usage and monitored each other's withdrawals, just as farmers in huerta villages restricted water usage to certain parcels of land and kept an eye on their neighbors' withdrawals. Second, a nested enterprise model in which management is "polycentric" rather than centralized, and in which appurtenant groups of organized users actively participate, ${ }^{229}$ can produce an allocation of tradable rights that is efficient and stable, as well as conducive to conservation. As clarification of rights has proved difficult under regulated riparianism, and a market in permits has failed to materialize, the achievements of the entities Ostrom describes are particularly noteworthy. In short, the horizontal governance model seems to have had more success in resolving efficiency and conservation problems than have eastern regulatory systems.

225. See supra notes 79-81 and accompanying text.

226. OSTROM, supra note 41 , at 113.

227. Id. at 135 .

228. Id. at 114 .

229. Id. at 133 . 
A fourth model - what we might call the umbrella model-is illustrated by local water institutions in the western United States. ${ }^{230}$ Mutuals and water districts are the retail distributors of most domestic water and much agricultural water in western states. ${ }^{231}$ Mutuals are private nonprofit corporations whose customers are also shareholders; water districts, on the other hand, are governed by elected boards, like other local government units. "Both types of institutions engage in a broad set of activities, including obtaining and storing necessary water supplies, transporting the water to their service areas, and distributing it to their members."232 For our purposes, mutuals and districts may be analogized to appurtenant groups (though the water they consume may come from a distant reservoir or dam), as they allow groups of local users to access water jointly, thereby taking advantage of economies of scale, and to maintain control over allocation within the group. ${ }^{233}$

These institutions have developed into multilayered regimes, thus exemplifying a more complex, cross-scale kind of nested enterprise than the models already discussed. Mutuals and water districts may obtain their water from a larger umbrella agency acting as a wholesaler, ${ }^{234}$ or they may sit within larger umbrella institutions themselves. ${ }^{235}$ All of these institutions ultimately sit under the general authority of the legislature.

Several features of these institutions are familiar. For instance, whereas users have generally been resistant to state proposals for conservation, they have been receptive to conservation programs implemented by local institutions. These programs have been able to reconfigure groundwater rights; impose well-spacing rules; institute pump taxes and import projects to optimize use of ground and surface water; and establish loan programs, conservation rebates, and, in some cases, tiered pricing structures. ${ }^{236}$ In short, appurtenant groups of users have, here as elsewhere, voluntarily recognized the need to conserve, and they have advanced creative methods to meet that need, but in a way that emphasizes local control.

230. While the West is governed by a different legal regime, namely appropriation, for determining water rights, the difference is unimportant in this context, where our focus is on the nonlegal, institutional, and organizational dynamics at work, rather than on the allocation of water under formal legal rights.

231. Thompson, supra note 80 , at 687 .

232. Id. at 688; see also id. at 687-89 (describing mutuals and water districts).

233. See id. at 689.

234. Id.

235. Id. at 718. Tom Tietenberg describes how water user associations in Chile perform "a considerable role in allocating water resources.... Although the [central agency] has broad authority in water resource management, much of the actual control over river flows is exercised by the Juntas de vigilancia, associations made up of all users and user associations on a common section of a river." Tietenberg, supra note 214, at 203 (citation omitted).

236. Thompson, supra note 80 , at 697 . 
Thompson also describes at length the failure of state governments to facilitate voluntary transfers: "Legal restrictions on formal water transfers pose insurmountable transaction costs for many small water users . ..,237 In response, users "have employed local institutions to obtain or exchange water." 238 Institutions provide members with "largely interchangeable water entitlements," allowing the development of standardized markets; members of institutions are also likely to be familiar with each other's needs; and many institutions have constructed extensive physical infrastructure that facilitates the transfer of water from one user to another. ${ }^{239}$ Finally, institutions have proved adept at allocating water during times of scarcity: They can "balance their service areas, water supplies, and storage capabilities .... [They] can also more readily calculate and enforce pro rata allocations. $" 240$ In the language of appurtenancy, physical, social, and functional proximity among users facilitates efficient trade and reallocation within the group.

Of course, mutuals and, to an even greater extent, districts can exhibit some of the less savory features of appurtenant communities as well. While they vary in size, and while some encompass a large geographic area and a range of users, their success seems due in part to the homogeneous-and sometimes insular-interests of their membership. Many mutuals are "enlivened with a dollop of community spirit."241 While such community spirit may make informal transfers between members less cumbersome than statutory transfers ${ }^{242}$ and encourage the adoption of stronger conservation measures than those imposed by the state, ${ }^{243}$ internal community norms also reflect the exclusionary tendencies and insider-outsider mentality that an appurtenant group of users can exhibit. In particular, Thompson notes the resistance of some local institutions to interjurisdictional transfers, such as "ag-urban" trades. ${ }^{244}$ Such resistance can often be the result of "parochical self-interest that is inconsistent with broader societal good." 245

Importantly, however, Thompson does not advocate complete centralization of control as the solution to this problem, and he is wary of

237. $I d$. at 676 .

238. Id. at 677 .

239. Id. at 710 .

240. Id. at 696.

241. Id. at 699 .

242. See id. at 721 (arguing that community norms against profit-making result in transfers that are "quite informal," and that parties use "social balance accounts" to keep track of trades).

243. See id. at 698 (observing that institutions have "supplement[ed] the weak conservation measures of state law," and that greater receptivity to such measures derives in part from the insular nature of such arrangements, which do not include "outsiders").

244. Id. at 723-34.

245. Id. at 731 ; see also id. at 733 (noting that "[w]orries about community impacts also motivate institutional opposition to external transfers"). 
stripping too much authority from local institutions and losing the benefits of appurtenancy described above:

Despite the potential advantages of creating larger water institutions ... attempts to enlarge or consolidate current institutions will inevitably encounter numerous problems and limitations....

... Legislatures therefore may do best by merely encouraging institutions to examine the advantages of forming larger units, and then making it as easy as possible for them to do so. ${ }^{246}$

This approach might best be described as more nesting - increased usage of intermediate, umbrella institutions that can facilitate interregional trades among various sets of appurtenant groups, ${ }^{247}$ and increased legislative support for such institutions. While Thompson recognizes that more heavyhanded state oversight may in some instances be necessary, ${ }^{248}$ his preferred solution is neither purely regulatory nor purely market-based, but is rather institutional. In the multilayered regime he proposes, larger associations can overcome obstacles to market trade that currently exist by producing internal economies of scale and internalizing the costs imposed by one group on others.

\section{Some Policy Suggestions}

Having reconceptualized appurtenancy as a principle of functional rather than physical proximity, and having determined that appurtenancy can function within a larger-scale nested regime, we can now begin to ask how such a regime might work in practice in the context of eastern water. The four models outlined above-reverse command-and-control, marketbased tradable allowances allocated to communities, horizontal governance, and increased nesting through umbrella organizations-may provide

246. Id. at 754 (footnote omitted).

247. See id. at 718-19 (describing the transfers between institutions that occur when those institutions are both members of a larger, umbrella wholesaling institution, and pointing out that "umbrella institutions typically aid transfers by creating standardized (and thus easily marketed) rights and by providing necessary transportation facilities"); id. at $722-23$ (describing the formation of new umbrella institutions among water districts in California and Washington to "ease the process of transferring water rights among themselves").

248. See id. at 723-24, 729 (explaining that districts have been resistant to external transfers, especially where such transfers would require conservation or lead to a long-term loss for the district); id. at 735 (suggesting that state and regional governments are better suited to answering the social policy questions surrounding intergroup transfers); id. at 740,746 (arguing that incentives and structural reform may not be enough to encourage external transfers and suggesting that in some cases, legislative overrides of institutional constraints on external transfers may be in order). 
policymakers with a starting point. Berkes, using different terminology, similarly suggests a range of ways in which states can facilitate cross-scale management, including "legitimization of local institutions," enabling legislation that gives authority to "locally devised rules," capacity building "at all levels," and "institution building." 249 What "legitimization" or "institution building" will mean in practice will depend on the particular institutional structure in place in each jurisdiction, and the types of user associations that exist or that might be formed. ${ }^{250}$ While a comprehensive policy proposal is beyond the scope of this Note, I would like to offer a few preliminary thoughts as to how policymakers might incorporate appurtenancy into eastern water management.

Given the efficiency and equity concerns posed by purely local organizations, state regulatory agencies should retain ultimate authority over the allocation of water rights. The question, then, is how states might recognize appurtenant groups and include them-formally or informallyin water management decisions. Perhaps the simplest option would be to encourage the development of voluntary user associations, without providing such groups any formal legal recognition. Such an arrangement would allow appurtenant groups to form through self-identification, perhaps utilizing industry or interest groups already in existence. ${ }^{251}$ States could offer encouragement in several ways. As Ostrom's study of groundwater basins in southern California demonstrates, provision of a public forum for users can facilitate negotiation, information-sharing, clarification of rights, and adoption of voluntary constraints by users. ${ }^{252}$ The state might further support voluntary user action by offering assistance with informationgathering (recall the recordkeeping function provided by the state of Kumaon to local authorities) and the enforcement of any voluntary agreements among users (for example, enforcement of trap limits in Maine

249. Fikret Berkes, Cross-Scale Institutional Linkages: Perspectives from the Bottom Up, in THE DRAMA OF THE COMMONS, supra note 36, at 293, 299 tbl.9-2.

250. Florida, for example, is unique in institutional structure; it has divided responsibility for water management among five regional districts, which correspond "to the diverse matches across the state between need and availability of water." Dellapenna, The Law of Water Allocation, supra note 1 , at 60 . The districts make permitting decisions, but remain under the supervision of the state environmental protection agency. Flood \& Wright, supra note 141, at 119.

251. For example, ski resorts in Maine and Vermont that divert water from rivers in order to make snow for the slopes, see Bowman, supra note 31, at 292, may already be members of hotel industry associations. In Massachusetts, citizen organizations have formed an umbrella network, called the Massachusetts Water Watch Partnership, that provides training and technical assistance to members to conduct water quality monitoring. See Mass. Water Watch P'ship, at http://www.umass.edu/tei/mwwp/index.html (last visited Feb. 13, 2004). A similar organization has mobilized around the Mystic River watershed. See Mystic River Watershed Ass'n, at http://www.tufts.edu/mystic/index.htm (last visited Feb. 13, 2004). An additional benefit of the reconceptualized notion of appurtenancy-which emphasizes functional proximity to the resource and shared interests with other users - is that it allows for the inclusion of environmental groups within the range of appurtenant groups.

252. See supra notes $219-228$ and accompanying text. 
lobstering waters, and the provision of one-third of the costs of a monitor for groundwater basin withdrawals in southern California). This approach could be characterized as capacity-building or institution-building, within Berkes's taxonomy, and would in some respects parallel the reverse command-and-control model delineated above. The primary objective would be to aid in the development and enforcement of conservation norms developed voluntarily by those most familiar with the resource.

Beyond such informal facilitation, state regulators could explore a variety of ways to offer appurtenant groups more formal legal recognition. One possibility that could work within a modified version of existing permitting systems would be to issue blocks of permits to groups of users rather than to individuals, along the lines of the market-based tradable allowances model discussed earlier. Appurtenant groups might be defined according to categories of uses (for example, farming, residential water supply, commercial development, recreation). Such an arrangement would afford appurtenant groups a measure of management authority regarding their own usage. ${ }^{253}$ Freedom to trade and reallocate rights within groups could assist in the development of conservation measures and efficiency improvements. Appurtenant groups might also prove more effective at distributing water among members during times of scarcity and responding to fluctuations in user need and resource availability. The existence of a larger market of permits might also facilitate intergroup coordination. At the same time, a centrally administered permitting scheme would preserve the ability of state administrators to set certain policy goals (such as equitable distribution), to monitor overall usage, and to ensure coordination of different user groups.

***

My hope is that the examples of nested regimes and suggestions for eastern water offered in this Section will provide a starting point for the reassessment of regulated riparianism. Regulators should resist the tendency to call for greater centralization and regulatory control, and should question the assumption that ex ante decisions made by an administrative agency can alone solve the problems of scarcity and allocation that trouble

253. A change of this sort-which would shift permits, or some form of legal interest, into the hands of groups and away from individual users or entities-might raise constitutional questions. Given that the transition from common law riparian rights to permitting systems has generally survived Takings Clause challenges, however, I think it likely that a group-based permitting system, if constructed appropriately, would also survive such challenges. See Dellapenna, Riparianism, supra note 1, at 512-21 (describing the few and generally unsuccessful challenges to the adoption of permitting systems); see also GoULD \& GRANT, supra note 40, at 318-19 (observing that few commentators seem troubled as to the constitutional validity of permitting statutes). 
eastern water today. The institutional insights gleaned from appurtenancy doctrine should inform the shape of water management institutions going forward.

I have presented a few possible options for reincorporating appurtenancy into water management, without urging any particular approach. To a large extent, this Note remains agnostic as to the appropriate degree of state oversight, noting only that administrators should be attentive to the institutional model adopted, as certain regulatory forms may themselves produce inefficiencies. Specifically, regulators might find that cross-group coordination would best be achieved not via more assertive forms of regulation, which have proved disastrous in numerous arenas, but rather by market incentives ${ }^{254}$ or the formation of larger umbrella institutions encompassing multiple smaller user groups. On the other hand, a more aggressive regulatory approach may be necessary where parochial community interests produce cross-group inefficiencies or inequities that the market alone cannot resolve. Precisely what balance should be struck between appurtenant groups and state oversight in the management of eastern water is a question the Note does not seek to answer, and one whose answer will very likely be contextual. Having argued for multilevel governance and having sketched a few possibilities, this Note recognizes that the remaining challenge is to understand exactly what institutional design - what allocation of decisionmaking, monitoring, and enforcement functions-will best achieve the goals of efficiency, equity, and conservation in water usage and distribution.

\section{CONCLUSION}

At a time when eastern states face continuing water shortages, and regulated riparian statutes are in need of reassessment, this Note offers new

254. A thorough exploration of the continuing debate over command-and-control versus market-based regulatory policies is beyond the scope of this Note. A vast literature on this topic exists. Compare Bruce A. Ackerman \& Richard B. Stewart, Comment: Reforming Environmental Law, 37 STAN. L. REV. 1333, 1341-51 (1985) (arguing against command-and-control regulation and for market-based regulation), and Robert Stavins \& Bradley Whitehead, Market-Based Environmental Policies, in THINKING ECOLOGICALLY 105, 105 (Marian R. Chertow \& Daniel C. Esty eds., 1997) (arguing that the use of economic incentives in environmental regulation, while not a panacea, has "worked exceptionally well in a number of areas"), with Howard Latin, Ideal Versus Real Regulatory Efficiency: Implementation and "Fine-Tuning" Regulatory Reform, 37 STAN. L. REV. 1267, 1270-73 (1985) (advocating uniform command-and-control regulation). Here I would simply emphasize that certain elements of market- or incentive-based regulation seem broadly consistent with the principle of user management I have identified in appurtenancy doctrine. Market mechanisms - like the appurtenancy principle - are premised on user control and the efficiency of user-developed techniques and practices. See Thomas W. Merrill, Explaining Market Mechanisms, 2000 U. ILL. L. REV. 275, 276 (summarizing the argument for market-based mechanisms as being based on the "flexibility" and choice that such regulatory schemes give to users). 
ideas about water management by turning to two different sources of inspiration: the common law and the growing body of literature on common property regimes. Despite the criticism it has garnered, the appurtenancy requirement exhibits certain durable principles for conserving scarce resources that this Note seeks to highlight. Moreover, in comparing appurtenancy to reasonable use, this Note provides a new theoretical perspective-contrasting limiting and balancing rules-with which to assess resource management systems and the rules they impose. The Note puts these conclusions to work in its analysis of regulated riparianism, concluding that the retention of a reasonableness inquiry may undermine efforts to conserve scarce water supplies. Rejecting the efficacy of such open-ended balancing tests, the Note instead urges consideration of a new institutional model - the nested enterprise model - as a way to manage scarce resources. In the context of eastern water, the nested enterprise model may offer policymakers a way to incorporate a reconceptualized principle of appurtenancy - a principle that attends to scarcity and respects the expertise of users in conserving common resources-into the broader oversight and authority of the state. While the doctrinal rule may have faded, the core concepts of appurtenancy can thus have continuing relevance. Embedding those concepts in our water law and policy will better allow us to conserve and manage our water supply. 
***

Imaged with the Permission of Yale Law Journal 